SRNL-STI-2011-00190

Key Words: L Basin

Structural Integrity

Corrosion

Retention: Permanent

\title{
Demonstration of Long-Term Storage Capability for Spent Nuclear Fuel in L Basin
}

\author{
Savannah River National Laboratory
}

Publication Date: April 2011

Savannah River National Laboratory

Savannah River Nuclear Solutions

Aiken, SC 29808

Prepared for the U.S. Department of Energy Under Contract Number DE-AC09-08SR22470

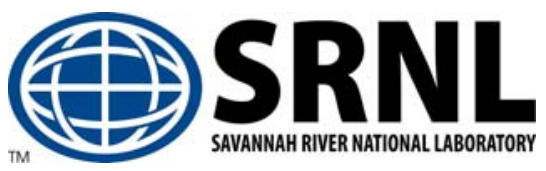




\section{DISCLAIMER}

This work was prepared under an agreement with and funded by the U.S. Government. Neither the U. S. Government or its employees, nor any of its contractors, subcontractors or their employees, makes any express or implied:

1. warranty or assumes any legal liability for the accuracy, completeness, or for the use or results of such use of any information, product, or process disclosed; or

2. representation that such use or results of such use would not infringe privately owned rights; or

3. endorsement or recommendation of any specifically identified commercial product, process, or service. Any views and opinions of authors expressed in this work do not necessarily state or reflect those of the United States Government, or its contractors, or subcontractors.

Printed in the United States of America

Prepared for

U.S. Department of Energy 
DOCUMENT: SRNL-STI-2011-00190

TITLE: Demonstration of Long-Term Storage Capability for Spent Nuclear Fuel in L Basin

Authors \& Editors: $\quad$ R.L. Sindelar, SRNL Materials Science \& Technology R.W. Deible, M\&O Engr., SFP Operations Engineering

Contributors: $\quad$ M.D. Dunsmuir, L-Area Project Operations

D.L. Speed, SFP Facility Engineering

R.B. Castles, SFP Operations Engineering

A.J. Duncan, Materials Science \& Technology

S.A. Carey, Structural Mechanics

N.A. Doulgerakis, Structural Mechanics 


\section{TABLE OF CONTENTS}

EXECUTIVE SUMMARY

LIST OF ABBREVIATIONS 3

1. INTRODUCTION 6

1.1. SAFETY FUNCTIONS FOR EXTENDED WET STORAGE OF FUEL IN L BASIN

1.2. SSCS FOR EXTENDED STORAGE

2. FUEL 7

2.1. FUEL INVENTORY - PRESENT AND EXPECTED L BASIN INVENTORY 7

2.2. ALUMINUM-CLAD FUEL AND ALUMINUM FUEL STORAGE RACK $\begin{array}{lr}\text { SYSTEM DEGRADATION } & 12\end{array}$

2.3. WATER QUALITY FOR ALUMINUM FUEL IN WET STORAGE

3. FUEL STORAGE SYSTEMS 15

3.1. EBS 16

3.2. HTS (HORIZONTAL RACKS) 17

3.3. BUCKET STORAGE 18

$\begin{array}{lll}\text { 3.4. OS CANS } & 18\end{array}$

3.5. FUEL RECOVERY FROM OS CANS 21

4. WATER CHEMISTRY CONTROL SYSTEM 23

4.1. DESCRIPTION 23

4.2. ANALYSIS OF TIME OFF-LINE 24

4.3. MAINTENANCE OF WCCS 26

4.4. PORTABLE DEIONIZATION 26

4.5. WATER CHEMISTRY MONITORING 26

4.6. CORROSION SURVEILLANCE 27 
4.7. EXPECTED FUEL LIFE IN L BASIN

4.8. ADDITIONAL PROGRAM ACTIVITIES TO VALIDATE EXTENDED FUEL LIFE

5. L BASIN STRUCTURE 30

5.1. L BASIN STRUCTURAL ANALYSIS 31

5.2. L BASIN MATERIALS CONDITION 32

5.3. ADDITIONAL PROGRAM ACTIVITIES TO VALIDATE EXTENDED BASIN LIFE

6. CONCLUSIONS 35

7. REFERENCES 35 


\section{EXECUTIVE SUMMARY}

A large inventory of aluminum-clad, aluminum-based spent nuclear fuel, ${ }^{1}$ and other nonaluminum fuel owned by the U.S. Department of Energy is in wet storage in L Basin at the Savannah River Site. An evaluation of the present condition of the fuel, and the Structures, Systems, or Components (SSCs) necessary for its wet storage, and the present programs and storage practices for fuel management have been performed. Activities necessary to validate the technical bases for, and verify the condition of the fuel and the SSCs under long-term wet storage have also been identified. The overall conclusion is that the fuel can be stored in L Basin, meeting general safety functions for fuel storage, for an additional 50 years and possibly beyond contingent upon continuation of existing fuel management activities and several augmented program activities.

The fuel and the essential SSCs for extended wet storage of the fuel inventory in the

$\mathrm{L}$ Basin are determined to be the:

- Fuel

- Fuel Storage System

- Water Chemistry Control System

- Basin Structure

An evaluation of fuel and these SSCs for long-term wet storage has been performed. The following are the principal conclusions drawn in this evaluation:

- Fuel \& Fuel Storage - Standard Bundled Storage: The fuel in standard bundled storage configurations and the present and augmented program activities could enable and clearly demonstrate safe wet storage of the fuel for an additional 50 years of storage. An upper limitation in storage time would be due to the suspected result that corrosion damage to the aluminum fuel materials from general and localized corrosion, even in good quality water, will eventually collectively cause a large leakage rate from the inventory and adversely affect the ability to safely handle individual assemblies. Periodic inspection of the fuel and storage system materials is recommended to validate the minimal impact of the storage system and good water quality to degrade the fuel condition, and to verify the fuel condition. Fuel may be found to remain in good condition beyond the 50 year period.

\footnotetext{
${ }^{1}$ Used Nuclear Fuel or Used Fuel (UF) is the term presently used by U.S. Department of Energy - Office of Nuclear Energy to reflect that additional energy in the form of enriched uranium and plutonium remain in fuel presently discharged from commercial power reactors, and would be available to be recovered through reprocessing. Fuel that has little or no energy value would be termed "spent." It is recognized that the present body of information including international publications and regulations use the term "spent nuclear fuel" for discharged fuel, regardless of its energy value, and this term is also used in this report for the fuel stored in the L Basin.
} 
- Fuel \& Fuel Storage - Vented Storage: Damaged or cut test fuel is stored in J-tube isolation (oversize storage or OS) canisters made of stainless steel, and these fuel pieces are subject to continued degradation leading to high localized water activity as the fuel degrades, creating corrosion products within the isolation canisters. The fuel is recognized as being in a degraded or potential highly degraded condition, and it poses recovery and disposition challenges. The basic technologies and practices for fuel recovery are in place and have been successfully used in site fuel recovery operations at the Receiving Basin for Offsite Fuel (RBOF) and in an IAEA campaign. It is recommended that OS-specific evaluation be performed to predict the condition of the stored components with time and that planned fuel recovery methods be compared for alignment with the expected degraded condition.

- $\quad$ Fuel \& Fuel Storage - Sealed Underwater Storage: Some damaged or cut test fuel is stored in sealed canisters. Continued storage of fuel underwater in sealed (leaktight) canisters for 50 years and beyond is contingent on maintaining the leaktight system. An evaluation of the impact of leaking canisters is recommended to be performed. Also, an evaluation of the impact of the potential production of hydrogen within the sealed canisters by radiolysis of fuel oxyhydroxides is recommended for safe fuel retrievability.

- Water Quality Management System: The existing L Basin Water Chemistry Control System (WCCS) is sufficient to provide water quality conditions to minimize corrosion degradation of the fuel, storage racks, and other metal components in the L Basin. Periodic operation of the WCCS is necessary for fuel storage in L Basin. Routine maintenance is necessary to keep filter media effective and the build-up of radioactivity on the media with the facility safety basis. Portable deionization systems can be implemented as an alternate to the existing WCCS. There is no life time limit for service of a water quality control system due to this ability to provide portable systems as needed.

- Basin Structure: The L Basin concrete structure is degraded from its design condition. Loss of interior coating and minor cracking at locations in the basin has occurred with some minor seepage of water through the cracks. At present, the L Basin, a Performance Category $3 \mathrm{SSC}^{2}$, continues to contain water and has structural stability against defined Natural Phenomena Hazards (NPH) events. Only limited materials degradation would be expected in another 50 to 100 years from present. This expectation for L Basin to continue to contain water to provide a safe storage facility is contingent on continued monitoring of the L Basin material and structural conditions, together with standard maintenance.

\footnotetext{
${ }^{2}$ Performance Categorization of the L Basin is in accordance with DOE-STD-1021, "Natural Phenomena Hazards Performance Categorization guidelines for Structures, Systems, and Components," as reaffirmed April 2002.
} 


\section{LIST OF ABBREVIATIONS}

\begin{tabular}{|c|c|}
\hline AMA & Aging Management Activity \\
\hline AMP & Aging Management Program \\
\hline AMR & Aging Management Review \\
\hline ANL & Argonne National Laboratory \\
\hline ASME & American Society of Mechanical Engineers \\
\hline ASTM & American Society for Testing and Materials \\
\hline $\mathrm{BRC}$ & Blue Ribbon Commission on America's Nuclear Future \\
\hline BWR & Boiling Water Reactor \\
\hline $\mathrm{CC}$ & Criticality Control \\
\hline CFR & Code of Federal Regulations \\
\hline $\mathrm{CoC}$ & Certificate of Compliance \\
\hline DCSS & Dry Cask Storage System \\
\hline DSC & Dry Storage Canister \\
\hline DOE & Department of Energy \\
\hline DOT & Department of Transportation \\
\hline DSA & Documented Safety Analysis \\
\hline DWPF & Defense Waste Processing Facility \\
\hline EBS & $\begin{array}{l}\text { Extended Basin Storage (in reference to racks for vertical } \\
\text { tube storage) }\end{array}$ \\
\hline EIS & Environmental Impact Statement \\
\hline EM & Environmental Management (DOE) \\
\hline ER & Environmental Report \\
\hline EST & Extended Storage \& Transportation \\
\hline
\end{tabular}


FSAR Final Safety Analysis Report

GWd Giga-watt days

HEPA High Efficiency Particulate Air

HIC High Integrity Container

HLW High Level Waste

HPGe High Performance Germanium detector

HT Heat Transfer

INL Idaho National Laboratory

INTEC Idaho Nuclear Technology and Engineering Center

ITS Important to Safety

KSI Kips per Square Inch

LWR Light Water Reactor

MOX Mixed Oxide (typically plutonium and uranium oxides)

MPC Multipurpose Canister

MTHM Metric Ton Heavy Metal

MTU Metric Tonne of Uranium

MW Megawatt

N/A Not Applicable

NAC Nuclear Assurance Corporation

NDE Nondestructive Examination

NRC U.S. Nuclear Regulatory Commission

OS Oversize Storage (in reference to fuel storage canisters)

PB Pressure Boundary

PIE Post-Irradiation Examination

Psig pounds per square inch, gauge 


$\begin{array}{ll}\text { PVC } & \text { Polyvinyl Chloride } \\ \text { PWR } & \text { Pressurized Water Reactor } \\ \text { RBOF } & \text { Receiving Basin for Offsite Fuel } \\ \text { RS } & \text { Radiation Shielding } \\ \text { SAR } & \text { Safety Analysis Report } \\ \text { SCC } & \text { Stress Corrosion Cracking } \\ \text { SER } & \text { Safety Evaluation Report } \\ \text { SRP } & \text { Standard Review Plan } \\ \text { SSCs } & \text { Structures, Systems, or Components } \\ \text { SME } & \text { Subject Matter Expert } \\ \text { SNF } & \text { Spent Nuclear Fuel } \\ \text { SRS } & \text { Savannah River Site } \\ \text { SRNL } & \text { Savannah River National Laboratory } \\ \text { UNF } & \text { Used Nuclear Fuel (sometimes referred to as Used Fuel (UF)) } \\ \text { VLTS } & \text { Very Long-Term Storage } \\ \text { WCCS } & \text { Water Chemistry Control System }\end{array}$




\section{INTRODUCTION}

The U.S. Department of Energy decisions for the ultimate disposition of its inventory of used nuclear fuel presently in, and to be received and stored in, the L Basin at the Savannah River Site, and schedule for project execution have not been established. A logical decision timeframe for the DOE is following the review of the overall options for fuel management and disposition by the Blue Ribbon Commission on America's Nuclear Future (BRC). ${ }^{3}$ The focus of the BRC review is commercial fuel; however, the BRC has included the DOE fuel inventory in their review. Even though the final report by the BRC to the U.S. Department of Energy is expected in January 2012, no timetable has been established for decisions by the U.S. Department of Energy on alternatives selection. Furthermore, with the imminent lay-up and potential closure of H-canyon, no ready path for fuel disposition would be available, and new technologies and/or facilities would need to be established.

The fuel inventory in wet storage in the 3.375 million gallon L Basin is primarily aluminum-clad, aluminum-based fuel of the Materials Test Reactor equivalent design. An inventory of non-aluminum-clad fuel of various designs is also stored in L Basin. Safe storage of fuel in wet storage mandates several high-level "safety functions" that would be provided by the Structures, Systems, and Components (SSCs) of the storage system.

\subsection{SAFETY FUNCTIONS FOR EXTENDED WET STORAGE OF FUEL IN L BASIN}

The DOE-owned fuel in L Basin is primarily from research and test reactors. Degradation of research fuel in storage systems should be limited to avoid adverse impacts to the general safety functions. Safety functions have been prescribed by the International Atomic Energy Agency for stored research reactor fuel [1], [2], and for commercial fuel [3]. These safety functions are for the SSCs of the fuel storage system to:

- maintain criticality safety;

- maintain cooling of the fuel;

- maintain general confinement by the fuel/clad system ${ }^{4}$

\footnotetext{
${ }^{3}$ The Blue Ribbon Commission on America's Nuclear Future (the Commission) was established in accordance with the provisions of the Federal Advisory Committee Act (FACA), as amended, 5 U.S.C. App. 2, and as directed by the President's Memorandum for the Secretary of Energy dated January 29, 2010: Blue Ribbon Commission on America's Nuclear Future. This charter establishes the Commission under the authority of the U.S. Department of Energy (DOE). ${ }^{4}$ In many interim storage systems, the cladding is not typically credited to provide confinement in the safety basis. Nevertheless, large breaches may cause undesired gross release of radioactivity, and for this reason, general confinement provided by the fuel/clad system in interim storage should be maintained.
} 
- maintain the ability to retrieve the fuel; and

- maintain options for ultimate disposition

The Documented Safety Analysis for L-area [4] and Technical Safety Requirements [5] provides specific limits and conditions for the safety of fuel storage in L Basin to meet the federal regulations [6] and L-area and site safety criteria.

\subsection{SSCS FOR EXTENDED STORAGE}

The fuel and three SSCs are essential for safe fuel storage in L-Basin. These include:

- Fuel - Present fuel inventory includes approximately 12,000 aluminum-clad, aluminum-based research reactor fuel assemblies of the plate fuel or Materials Test Reactor equivalent design. There are approximately 2000 non-aluminum clad fuel assemblies in L Basin

- Fuel Storage Systems - Present storage systems include Vertical Tube Storage of fuel within a bundle or aluminum tube; bucket storage; and Oversize (OS) can storage.

- Water Chemistry Control System - Present system is a ion exchange resin deionizer and sand filter

- Basin Structure - The L Basin is a 3,375,000 gallon reinforced concrete structure.

The present condition, the potential for degradation, and the management practices to avoid degradation of the materials of the fuel and SSCs are described. An estimation of the life time of these SSCs is provided, and practices to enable long-term storage are recommended.

\section{FUEL}

An inventory of research and test reactor fuels at the site had been in extended storage in the Receiving Basin for Offsite Fuel (RBOF) facility. The RBOF was a smaller size basin (approximately 500,000 gallons) in which fuel was in extended storage with good water quality maintained at $1-3 \mu \mathrm{S} / \mathrm{cm}$ using mixed-bed, continuously operated deionizers. When the production reactors were permanently shut down, most of the production reactor fuel was processed. All remaining wet-stored fuel at the site that had not been processed was transferred to the L Basin by the year 2003, including the fuel from RBOF. Some fuel in dry storage remained in K-area for several additional years before its transfer to L-Basin. At present, all wet storage is in L Basin.

\subsection{FUEL INVENTORY - PRESENT AND EXPECTED L BASIN INVENTORY}

Test fuel from site and commercial domestic reactors, and from Foreign and Domestic Research Reactors is storage in the L Basin. The commercial test fuel was initially 
received at SRS at RBOF beginning in the mid-1960s. This fuel was transferred to L Basin by 2003 along with the inventory of research reactor fuel in RBOF.

The Savannah River Site has received and continues to receive aluminum-clad, aluminum based fuel under the NEPA EIS [7, 8, 9] Additional aluminum fuel not initially considered in the program termed "gap" material is also being received.

The L Basin inventory is the following:

\section{Basin Inventory - Aluminum Fuel}

Aluminum-based fuel includes fuel with $\mathrm{UAl}_{x}, \mathrm{U}_{3} \mathrm{Si}_{2}$, and $\mathrm{U}_{3} \mathrm{O}_{8}$ dispersoids in an aluminum matrix. Aluminum cladding is used on the aluminum fuel. The total projected inventory of various design and operational histories of these materials are listed below. The SRS SNF EIS contains a listing of fuel allowed to be received and stored at SRS.

Baseline: 194 HFIR and 14,785 FRR/DRR Material Test Reactor Equivalent (MTRE)

Non- Baseline: FRR: 1000 HEU Canada NRU/NRX

Gap Material Baseline: 69 Chile

Gap Material Non-Baseline: 770 South Africa

To date, there are approximately 12,000 MTRE (as shown in Figure 1) in L Basin, including the Gap Material from Chile, and 118 HFIR cores in L Basin. Additional information on expected fuel receipts is contained in references 10 and 11

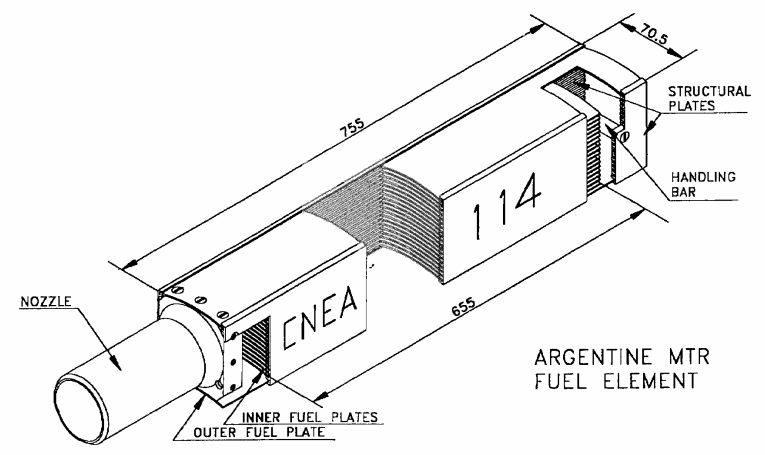

\section{Figure 1 Material Test Reactor Equivalent Design}

The aluminum fuel is of low heat output, and no active cooling of the basin water is needed. Table 1 below from reference 12 shows that fuel of discharge of 10 to 20 years from a research reactor, would be expected to be several watts per MTRE assembly. 
Table 1 Decay Heat (watts) for an Aluminum MTRE Assembly [table from reference 12]

\begin{tabular}{|r|c|c|c|c|}
\hline \multirow{2}{*}{$\begin{array}{c}\text { Decay Time (yr) } \\
\text { from Reactor } \\
\text { Discharge }\end{array}$} & \multicolumn{4}{|c|}{ Aluminum Fuel Heat Generation (watts) } \\
\cline { 2 - 5 } & HEU & LEU & Nominal Fuel \\
\hline 1 & 105.23 & 108.89 & 45.18 & HEU \\
2 & 45.64 & 47.67 & 20.05 & 46.61 \\
3 & 26.14 & 27.24 & 11.55 & 20.88 \\
6 & 11.30 & 11.52 & 5.200 & 12.00 \\
10 & 8.52 & 8.580 & 4.010 & 5.260 \\
20 & 6.367 & 6.530 & 3.023 & 4.030 \\
30 & 4.997 & 5.243 & 2.371 & 3.073 \\
60 & 2.480 & 2.830 & 1.163 & 2.453 \\
100 & 1.010 & 1.382 & 0.461 & 1.284 \\
200 & 0.144 & 0.487 & 0.055 & 0.594 \\
300 & 0.0438 & 0.3442 & 0.0128 & 0.179 \\
600 & 0.0133 & 0.2218 & 0.0036 & 0.1224 \\
1,000 & 0.0078 & 0.1468 & 0.0023 & 0.0826 \\
2,000 & 0.0043 & 0.0794 & 0.0015 & 0.0574 \\
3,000 & 0.0035 & 0.0630 & 0.0012 & 0.0345 \\
6,000 & 0.0028 & 0.0505 & 0.0010 & 0.0285 \\
10,000 & 0.0024 & 0.0410 & 0.0009 & 0.0232 \\
20,000 & 0.0017 & 0.0265 & 0.0006 & 0.0187 \\
50,000 & 0.0011 & 0.0103 & 0.0004 & 0.0120 \\
100,000 & 0.0009 & 0.0034 & 0.0003 & 0.0046 \\
& & & & 0.0014 \\
\hline
\end{tabular}

\section{Basin Inventory - Non-Aluminum Fuel}

Non-aluminum-clad fuel is stored in L Basin with full assemblies stored in bundled storage, and pieces stored within cans in either oversize can storage or bucket storage. The information in Table 2 was drawn from references 13 and 14. No new nonaluminum fuel is projected to be received in L Basin. 
Table 2 Non-Aluminum-Clad Fuel in L Basin [April 2011 LANMAS Data]

\begin{tabular}{|c|c|c|c|c|c|}
\hline Fuel Type & Fuel Core & Fuel Clad & Assemblies/Cans & Bundles & Kg HM \\
\hline EBWR & $\begin{array}{l}\mathrm{UO} 2-\mathrm{ZrO} 2- \\
\mathrm{CaO} \text {; U-Zr- } \\
\mathrm{Nb} \text { UO2- } \\
\text { Eu2O3- } \\
\mathrm{Sm} 2 \mathrm{O} 3 ; \\
\text { UO2-PuO2 }\end{array}$ & $\mathrm{Zr}-2 ; \mathrm{Zr}-4$ & 358 & 159 & 9980.75 \\
\hline HWCTR & $\begin{array}{l}\text { U metal; } \\
\text { UO2; U-Zr; } \\
\text { U-Si; U-Mo; } \\
\text { U-Fe/Al; U- } \\
\text { Fe/Al/Si; Th. } \\
\text { U }\end{array}$ & Zr-2; Zr-4; SS & 488 & 91 & 2066.07 \\
\hline Elk River & UO2/ThO2 & SS & 190 & 38 & 5030.89 \\
\hline Dresden Nuclear Power & $\begin{array}{l}\text { UO2; ThO2- } \\
\text { UO2 }\end{array}$ & SS & 30 & 30 & 2457.34 \\
\hline GCRE & \begin{tabular}{|l|}
$\mathrm{UO} 2 ; \mathrm{UO} 2-$ \\
$\mathrm{BeO} 2$
\end{tabular} & Hastelloy X; SS & 139 & 27 & 119.17 \\
\hline Saxton & $\begin{array}{l}\mathrm{UO} 2 ; \mathrm{UO} 2- \\
\mathrm{PuO} 2\end{array}$ & $\mathrm{Zr}-2 ; \mathrm{Zr}-4 ; \mathrm{SS}$ & 689 & 18 & 390.07 \\
\hline HTRE & $\begin{array}{l}\mathrm{Y} 2 \mathrm{O} 3-\mathrm{UO} 2 \\
\text { in } \mathrm{BeO}\end{array}$ & No cladding & 13 & 7 & 4.04 \\
\hline CVTR & $\mathrm{UO} 2$ & $\mathrm{Zr}$ & 34 & 3 & 67.47 \\
\hline Vallecitos BWR & U-Zr; UO2 & $\mathrm{Zr}-2$ & 7 & 2 & 4.04 \\
\hline Light Water Reactors & $\begin{array}{l}\text { UO2; PuO2 } \\
\text { UO2 }\end{array}$ & Zr-4; SS & 5 & 2 & 12.83 \\
\hline SPERT & UO2 & $\mathrm{Zr}-2$ & 3 & 2 & 9.74 \\
\hline ANL-MXOX & UO2/PuO2 & SS & 9 & 1 & 1.25 \\
\hline Shipping Port & $\mathrm{UO} 2$ & $\mathrm{Zr}-2$ & 4 & 1 & 16.11 \\
\hline HB Robinson & UO2 & $Z r-4$ & 3 & 1 & 1.00 \\
\hline Hanford Eng. Dev. Lab & UO2-PuO2 & SS & 2 & 1 & 2.72 \\
\hline $\mathrm{B} \& W$ & UO2-PuO2 & SS & 1 & 1 & 0.07 \\
\hline SRE Clad UC & $\mathrm{UC}$ & SS & 1 & 1 & 44.34 \\
\hline SRE Declad U-Th & U-Th & declad U-Th & 36 & 36 & 2126.93 \\
\hline Total & & Total & 2012 & 421 & 22334.83 \\
\hline
\end{tabular}



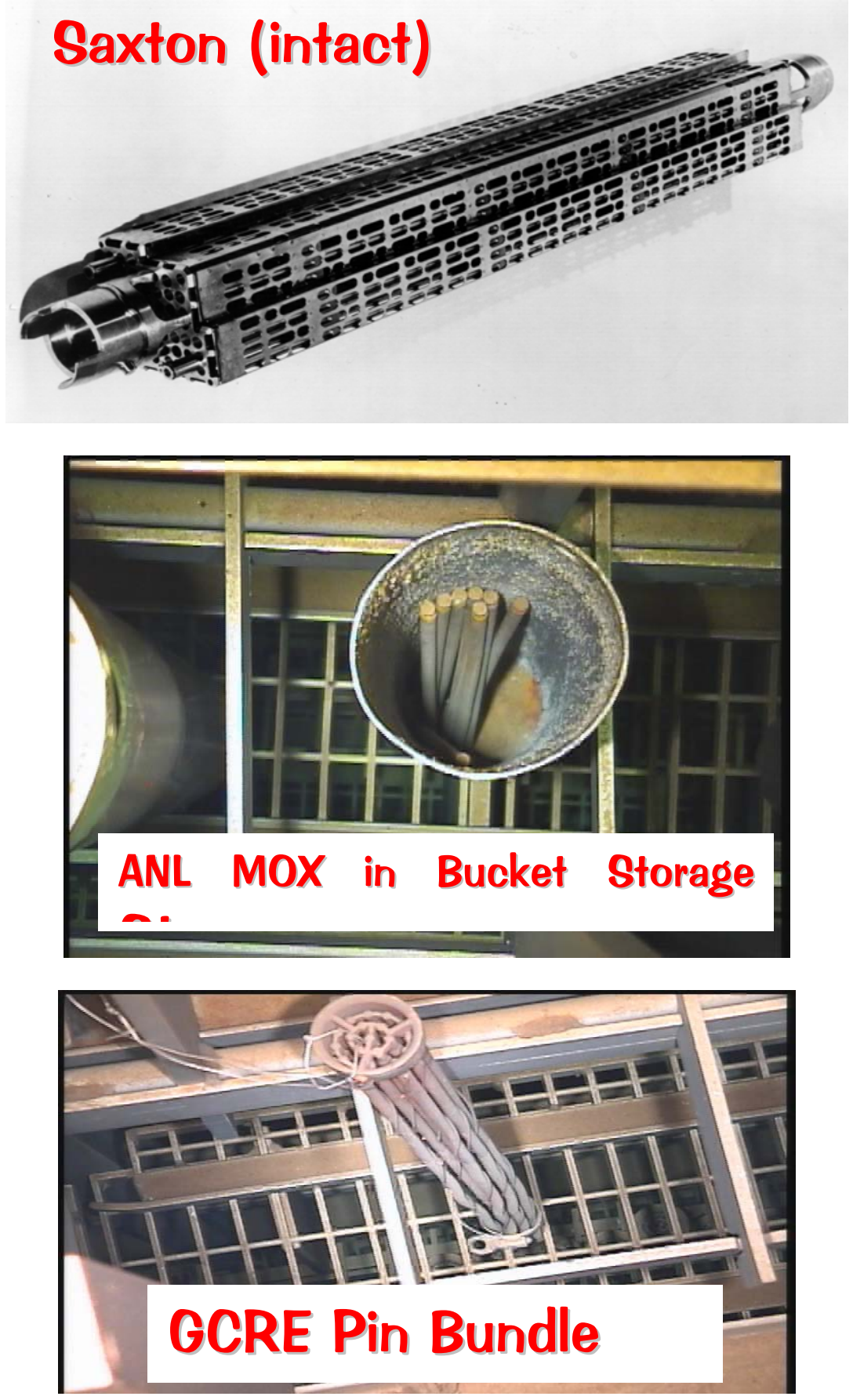

Figure 2 Examples of Non-Aluminum Fuel at SRS. The ANL MOX and GCRE Pin Bundle are photographs of this fuel when it was stored in RBOF. 


\subsection{ALUMINUM-CLAD FUEL AND ALUMINUM FUEL STORAGE RACK SYSTEM DEGRADATION}

Aluminum cladding alloys are susceptible to corrosion attack in water, whereas stainless steel and zirconium cladding alloys are much higher in resistance in reactor systems [15].

Aluminum cladding alloys in water pool storage are susceptible to rapid corrosion attack if the water is of poor quality. Figure 3 shows an example of the corrosion attack on two Material Test Reactor design (multiple fuel plates in a "box" assembly) assemblies that had been stored for between 12 to 26 years in poor quality water.
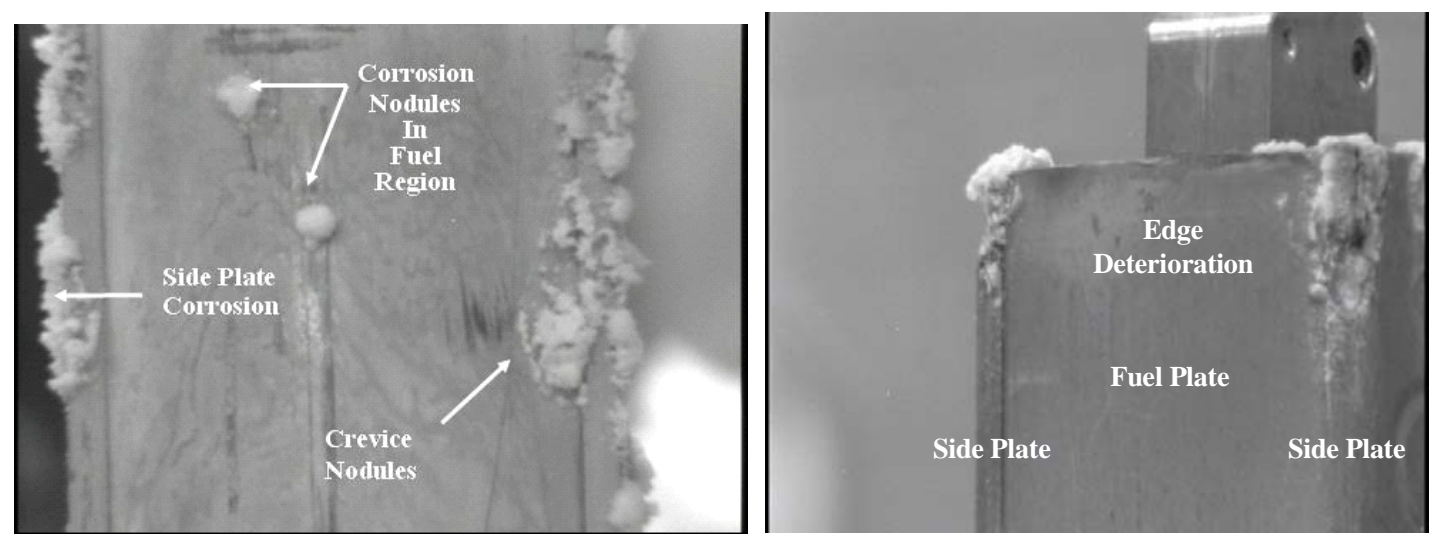

Figure 3 Aluminum-based, aluminum-clad spent nuclear fuel in moderately degraded condition post-irradiation and storage.

The above fuel was discharged from the RA-3 Research and Test Reactor and stored at the Comision Nacional de Energia Atomica (CNEA) Ezeiza Atomic Center near Buenos Aires, Argentina. Storage was under poor water quality $(\sim 80-170 \mu \mathrm{S} / \mathrm{cm}$ during storage) conditions. The photographs show (a) corrosion product evidence of pitting corrosion attack and crevice corrosion attack; and (b) evidence of galvanic attack with the two different aluminum alloys coupled at the location of the fuel plate and side structural plate.

If corrosion degradation continued, the fuel would ultimately lose structural stability for handling. Breach of the cladding and extension of the breached area with time would cause the continued, increasing release of its radionuclide inventory. It is important to note however, that no strong galvanic couple has been observed in laboratory testing in high quality water, and in field observations between the aluminum-clad and the aluminum-based fuel. That is, if cladding is breached in the high quality water of L Basin, the fuel meat and cladding tend to corrode congruently.

The following is a list of types of potential corrosion of attack, and that, except for stress corrosion cracking and erosion-corrosion, have been observed in aluminum alloy cladding of research reactor fuel as a result of water storage in poor water quality conditions [15]. 


\section{Table 3 Types of Corrosion Attack to Metals in Water}

1. General Corrosion

2. Pitting Corrosion

3. Crevice Corrosion

4. Galvanic Corrosion

5. Intergranular Corrosion

6. End-Grain Attack

7. Blister Formation

8. Microbial Corrosion

9. Sediment-Induced Corrosion

10. Stress Corrosion Cracking

11. Erosion-Corrosion

These types of corrosion can be minimized by storage in water of "good" water quality.

\subsection{WATER QUALITY FOR ALUMINUM FUEL IN WET STORAGE}

The IAEA has developed a guide for water quality for research reactor systems [15]. Table 4 below contains the recommended water quality limits for aluminum fuel in a storage basin. The limits were based on empirical cases of storage including those of the Savannah River basins, and are aimed to provide for minimum corrosion degradation. 
Table 4. Recommended physical-chemical parameters, limits, and monitoring frequencies for water in fuel decay and storage basins [15]

\begin{tabular}{lcc}
\hline PARAMETER & VALUE (LIMIT) & $\begin{array}{c}\text { MONITORING } \\
\text { FREQUENCY }\end{array}$ \\
\hline pH & 4.5 to 7 & weekly \\
Conductivity & $<10 \mu \mathrm{S} / \mathrm{cm}$ & weekly \\
Solids & $<5 \mathrm{mg} / 1$ & Every 6 months \\
$\mathrm{Cu}$ Concentration & $<0.1 \mathrm{mg} / 1$ & Every 6 months \\
$\mathrm{Cl}$ Concentration & $<0.1 \mathrm{mg} / 1$ & Every 6 months \\
Nitrate $\left(\mathrm{NO}_{3}{ }^{-}\right), \mathrm{mg} / 1$ & $<10 \mathrm{mg} / \mathrm{l}$ & Every 6 months \\
Sulphate $\left(\mathrm{SO}_{4}{ }^{2-}\right), \mathrm{mg} / 1$ & $<10 \mathrm{mg} / 1$ & Every 6 months \\
Fe Concentration & $<1.0 \mathrm{mg} / 1$ & Every 6 months \\
Al Concentration & $<1.0 \mathrm{mg} / 1$ & Every 6 months \\
Temperature & $<45^{\circ} \mathrm{C}$ & monthly \\
Radioactivity level $(*)$ & (see note below) & weekly \\
Turbidity $(* *)$ & (see note below) & \\
\hline
\end{tabular}

(*) Water Radioactivity level and the presence of radioisotope species should be measured each time a water sample is drawn or one time per week. A gamma scan is recommended to measure the presence of radioisotopes that would have come from failed fuel (e.g. Cs-137). No specific limits are set. The presence of radioisotope species should be evaluated on case-by-case basis. Measurement of the activity from filters and resin columns should be performed to detect the presence of leaking fuel.

$(* *)$ Turbidity should be reduced, as necessary, to provide visual clarity in the water system.

The operational limits for L Basin are below in Table 5. It is important to maintain these water quality conditions for the bulk water in L Basin to avoid aggressive corrosion of aluminum fuel and storage system materials.

Table 5. L Basin Water Operational Limits $[1 \mathrm{ppm}=1 \mathrm{mg} / \mathrm{l}]$

\begin{tabular}{llc}
\hline $\begin{array}{l}\text { Water Quality } \\
\text { Parameters }\end{array}$ & $\begin{array}{l}\text { Operating } \\
\text { Limit }\end{array}$ & $\begin{array}{c}\text { Monitoring } \\
\text { Frequency }\end{array}$ \\
\hline $\mathrm{pH}$ & 5.5 to 8.5 & Weekly \\
Conductivity & $10 \mu \mathrm{S} / \mathrm{cm}$ & Weekly \\
Activity & Cs-137:500 dpm/ml & Weekly \\
& Alpha: $3 \mathrm{dpm} / \mathrm{ml}$ & Monthly \\
& Tritium: $0.4 \mu \mathrm{Ci} / \mathrm{ml}$ & Each 6 months \\
& $\left(8.88 \times 10^{5} \mathrm{dpm} / \mathrm{ml}\right)$ & \\
Cu Concentration & $0.1 \mathrm{ppm}$ & Each 6 months \\
$\mathrm{Hg}$ Concentration & $0.014 \mathrm{ppm}$ & Each 6 months \\
$\mathrm{Cl}$ Concentration & $0.1 \mathrm{ppm}$ & Each 6 months \\
$\mathrm{Fe}$ & $1.0 \mathrm{ppm}$ & Each 6 months \\
$\mathrm{Al}$ & $1.0 \mathrm{ppm}$ & Each 6 months \\
Temperature & $45^{\circ} \mathrm{C}$ & Weekly \\
\hline
\end{tabular}




\section{FUEL STORAGE SYSTEMS}

Research reactor fuel has been stored in L Basin since the late 1990s. Fuel is stored in L Basin in several systems, depending on fuel design and fuel condition. Figure 4 below shows the map of the present configuration of the L Basin fuel storage locations.

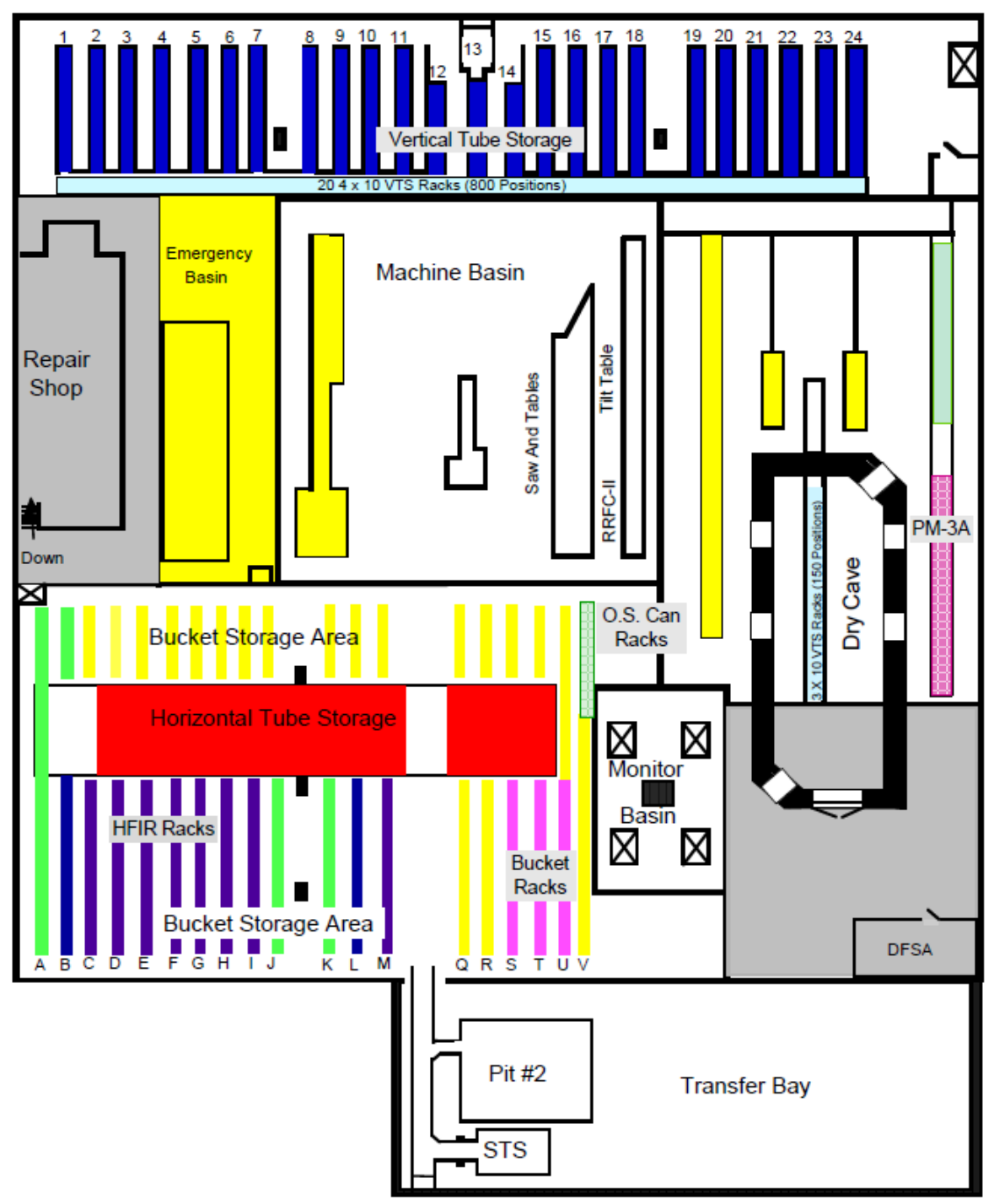

Figure 4. Layout of L Basin showing location of Fuel Storage Areas

Fuel is presently stored in several standard configurations, including EBS (or Vertical Tube Storage, VTS) racks, bucket racks, HFIR racks, OS can racks, and in various nonstandard customized configurations. Fuel in EBS rack storage is placed in L Basin bundles that are aluminum tubes containing typically up to five MTRE assemblies. Similar to corrosion degradation of the aluminum fuel cladding materials that can occur in poor quality water, the aluminum bundles (tubes) and storage rack materials are also subject to corrosion attack. 
Oversize storage (OS) cans are used to store severely damaged and failed fuel and fuel pieces. Damaged or degraded cladding or structural deformation of a fuel assembly, if significant, can result in radiological, criticality safety, waste, and accountability issues. The management of damaged spent nuclear fuel, including a description of the vented, oversize cans historically used at SRS for continued underwater storage of damaged fuel, is provided in reference 17.

\subsection{EBS}

Extended Basin Storage (EBS) or Vertical Tube Storage (VTS) consists of fuel bundled in aluminum tubes, each fitting in a $3 \times 10$ rack or a $4 \times 10$ rack as shown in Figure 5 and Figure 6 below. The racks are modular and can be placed adjacent to one another.

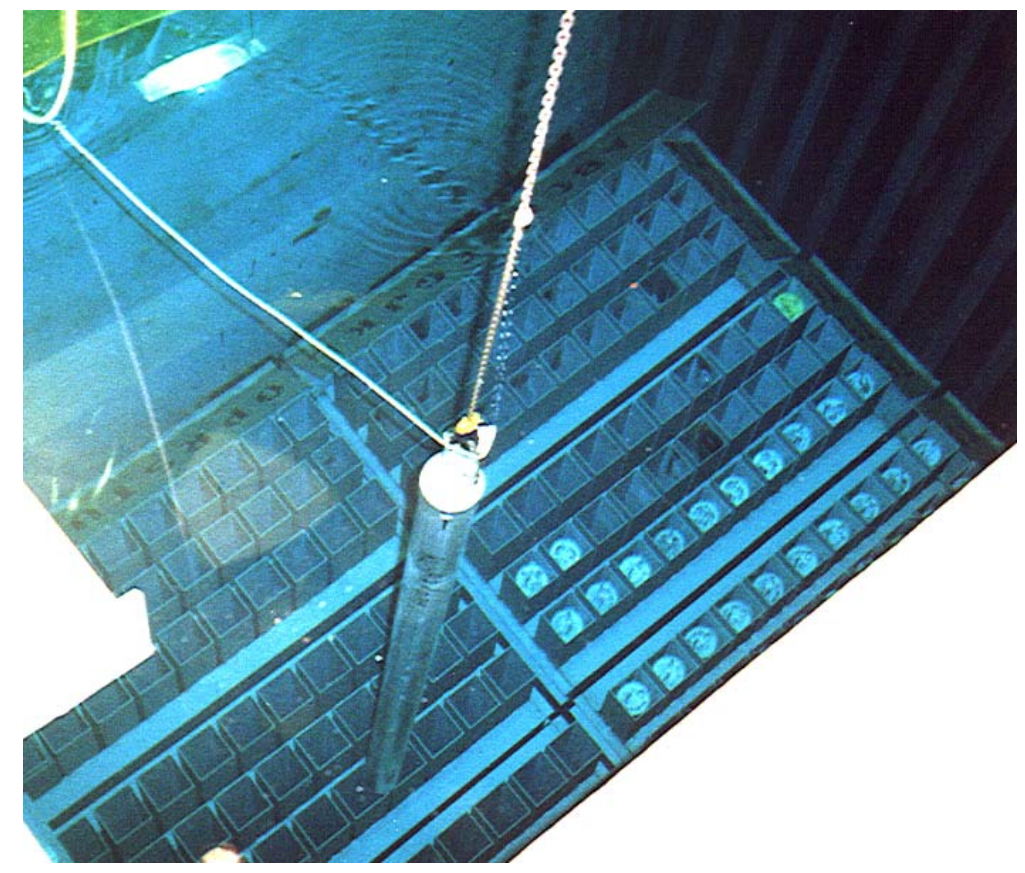

Figure 5. L-Bundle Being Inserted into the EBS Rack or Vertical Tube Storage 


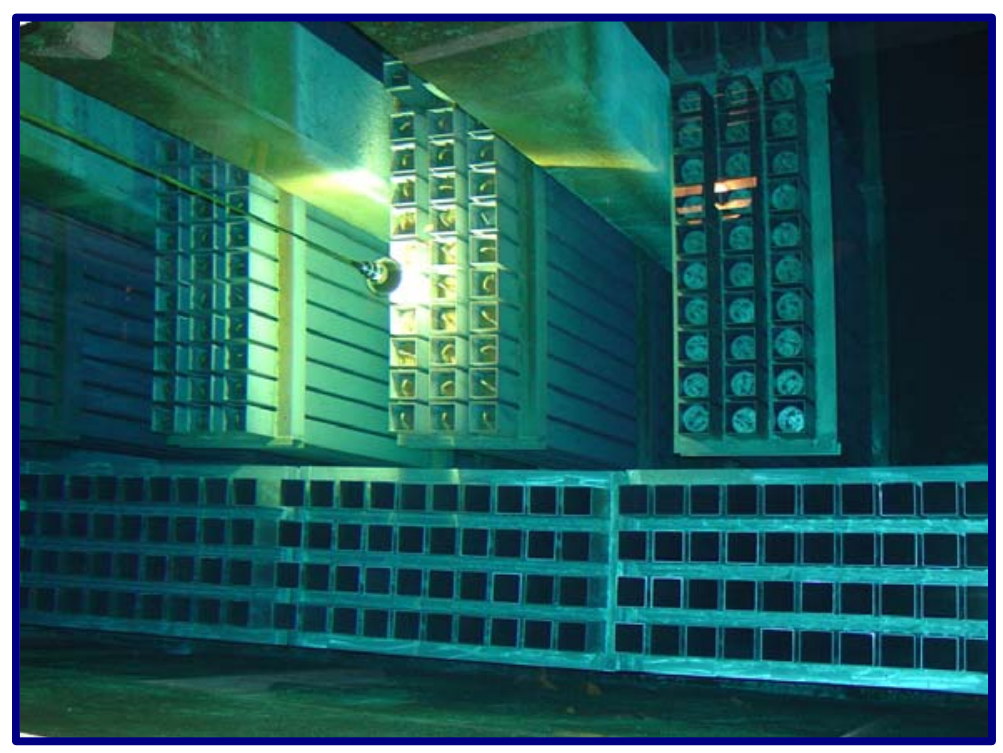

Figure 6. Installed $3 \times 10$ and $4 \times 10$ racks for EBS

\subsection{HTS (HORIZONTAL RACKS)}

Horizontal Tube Storage racks had been used to store bundles in L Basin. The aluminum racks that were installed in 1995 were removed and discarded in 2010.

Samples of the HTS racks were cut from the racks and sent to SRNL for comparison to the "Furniture rack" corrosion surveillance specimens. The surveillance coupons contain the rack alloy material (aluminum 6061-T6 and 6063-T5) and additional coupons with a weld bead line of the dissimilar aluminum weld alloy (R4043 weld filler material) that matches the weld alloy of the rack. These corrosion coupon specimens have shown an attack to the weld metal that is attributed to galvanically-induced corrosion (see Figure 7) [16], and analysis is in progress to compare the actual L Basin rack material condition to the coupons. 


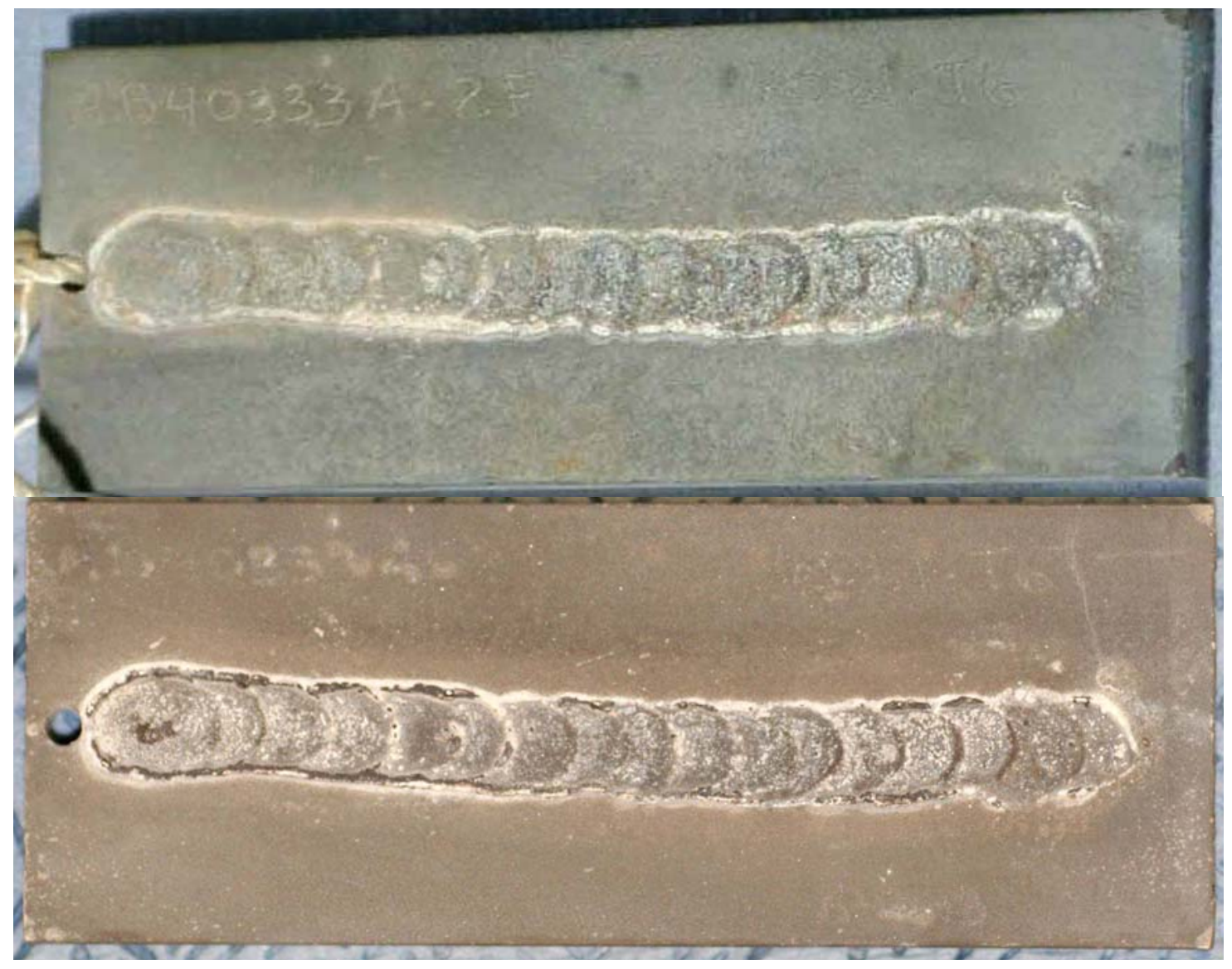

Figure 7. Welded plate corrosion coupon (1 1/2" $\mathrm{x}$ 4") of 6061-T6 with A14043 weld metal deposit as-received from immersion in the L Basin (A) and nitric acid cleaned to remove corrosion product oxide (B) [figure reproduced from reference 16]

\subsection{BUCKET STORAGE}

Bucket storage is storage of fuel in a variety of containers or buckets that are open at the top. The buckets are made of stainless steel and are used for fuel that is not amenable to bundled storage.

\subsection{OS CANS}

SRS chose isolated storage in water for the significantly damaged and cut fuel, separating it from the remainder of the basin water by loading it into large water-filled cans. The method of storing damaged fuel underwater was to place fuel pieces in small diameter cans (some aluminum and some stainless steel) which were grouped with others and placed in larger aluminum vessels referred to as oversized storage (OS) cans.

Isolation canisters for damaged SNF are designed to allow underwater storage of the highly damaged fuel while containing the radionuclide activity that can be released from it. Containing the released activity is important from the standpoint of radiological protection of basin operations personnel and reducing waste generated by more frequent 
regeneration/replenishment of basin deionizer resin beds. The present OS can design used in L Basin is shown below:

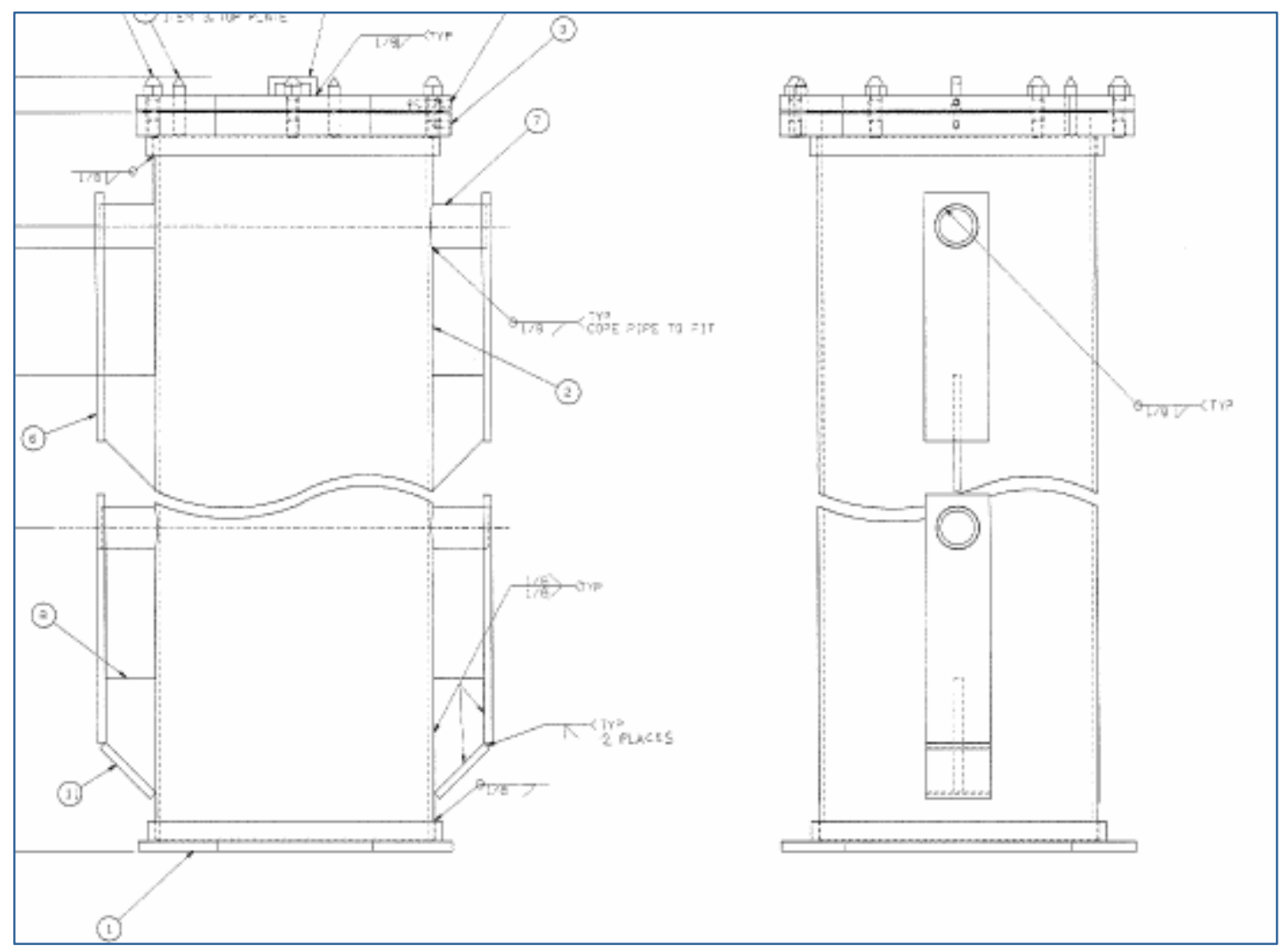

Figure 8. L Basin Oversize Can Design

A common design feature in the SRS-design OS canisters is a J-tube in the lid of the canister. J-tubes are similar to a P-trap on a household sink. Gases released from damaged SNF build up at the top of the can, separating the internal water environment from the main basin. The open design of the original J-tubes made them susceptible to silt buildup and pluggage. Valved couplings were added to avoid this problem, but this restricted the free flow of gas from the canisters. To minimize the potential for pluggage of the tube with debris, changes in the J-tube design were made (Figure 9). 


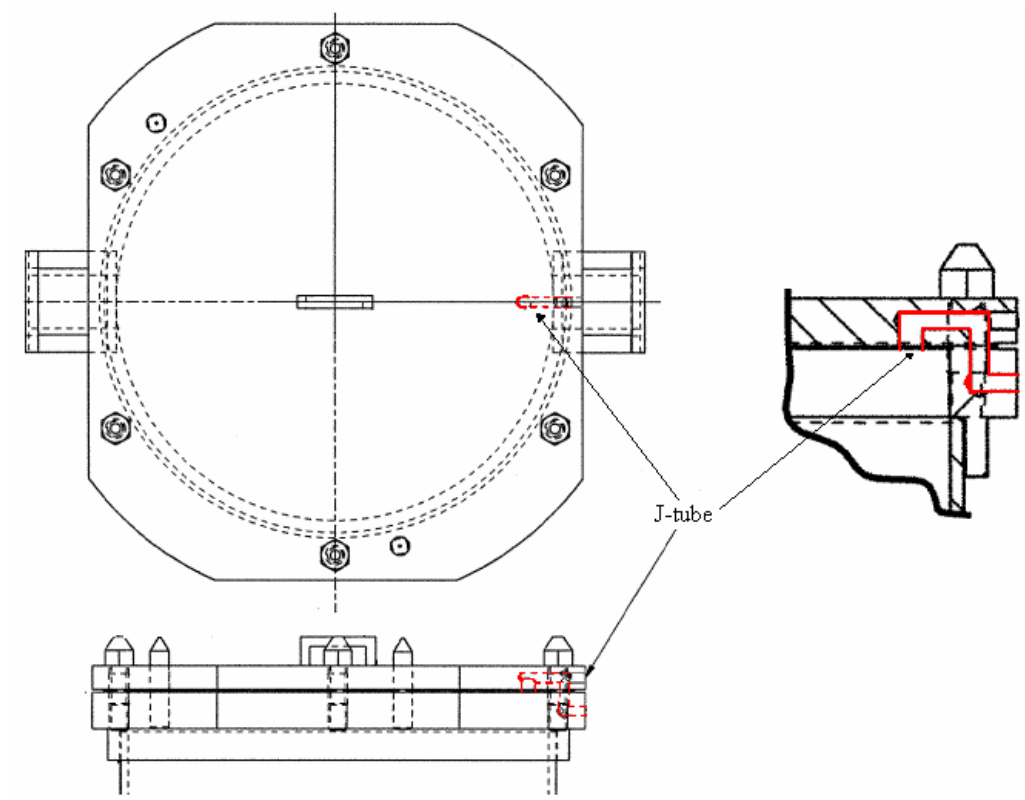

Figure 9. Later J-tube design on damaged-fuel storage can.

Figure 9 shows that, with the opening at the top of the canister, very little gas buildup is needed to separate the two water environments.

Gas emanating from the fuel could be vented out of the OS can through the j-tube if desired. Couplings were affixed to the end of both of these tubes, isolating the contents of the OS cans from the basin, but providing a path to flush water through the vessel or take water samples.

There are four storage racks for the OS cans in L Basin including:

- 3 Dresden Type Racks

- 36 Positions

- Aluminum Construction

- 5'-10" x 4'-8" x 12'-10" H (13" x 13" cells)

- 1 Saxton Type Rack

- 6 Positions

- Aluminum Construction

- 5'-10” x 4'-8” x 12'-10" H (16" x 16" cells) 


\subsection{FUEL RECOVERY FROM OS CANS}

As described above, the water in the OS cans is isolated from the general basin water, and the expected high activity water and corrosion product debris within the OS cans may require special recovery planning and preparation for eventual fuel recovery to avoid release to the general basin water.

A submersible deionizer was designed and built in 2003 and deployed in the Receiving Basin for Offsite Fuel to capture dissolved radioactive cesium from within OS containers in RBOF that contained inner cans with damaged or cropped test fuel pieces as shown in Figure 10 and Figure 11. The system (see Figure 12) generated no liquid waste and maintained the fuel storage basin radioactivity levels within limits. An overview of the use of the deionizer in the RBOF OS fuel recovery campaign is provided in reference [17].

The deionizer resin column used in the RBOF deinventory campaign is stored in an OS container in L Basin at present.

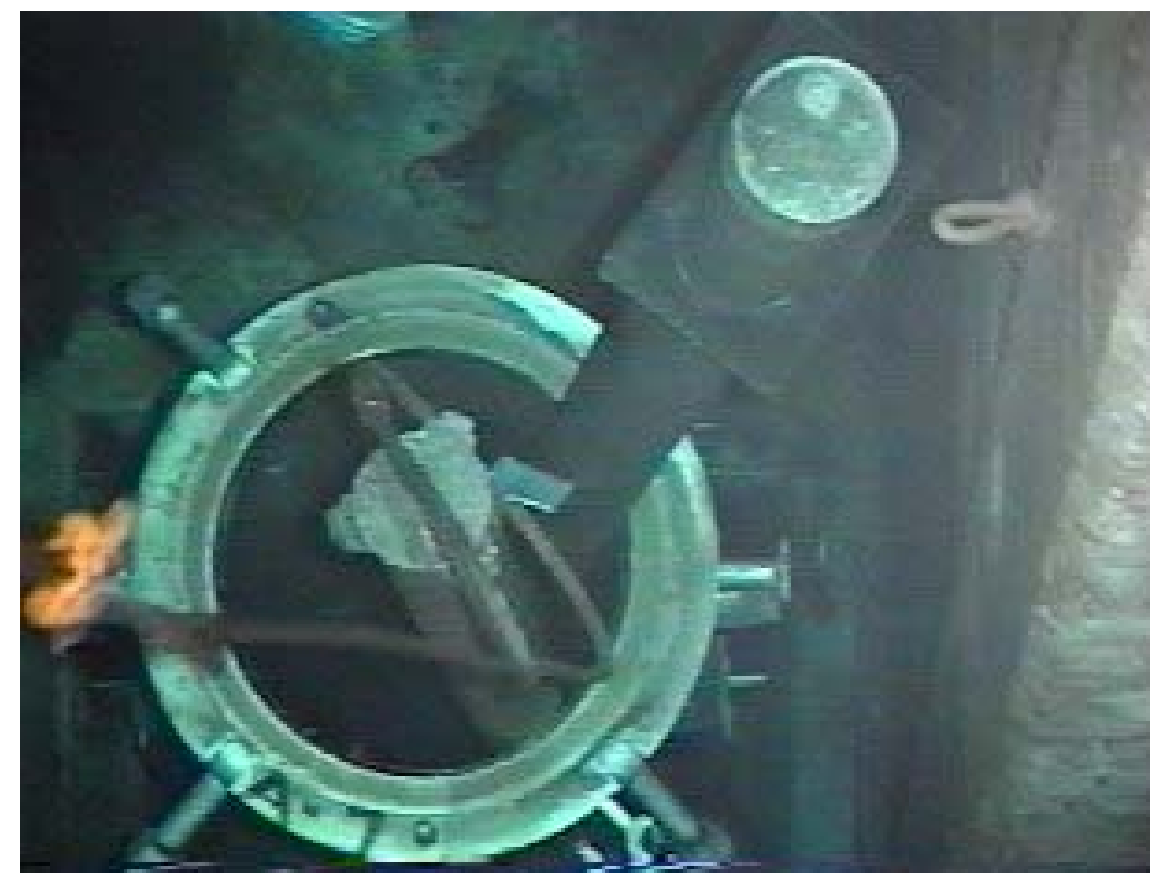

Figure 10. RBOF OS Can Lower Half/Contents After Flushing 


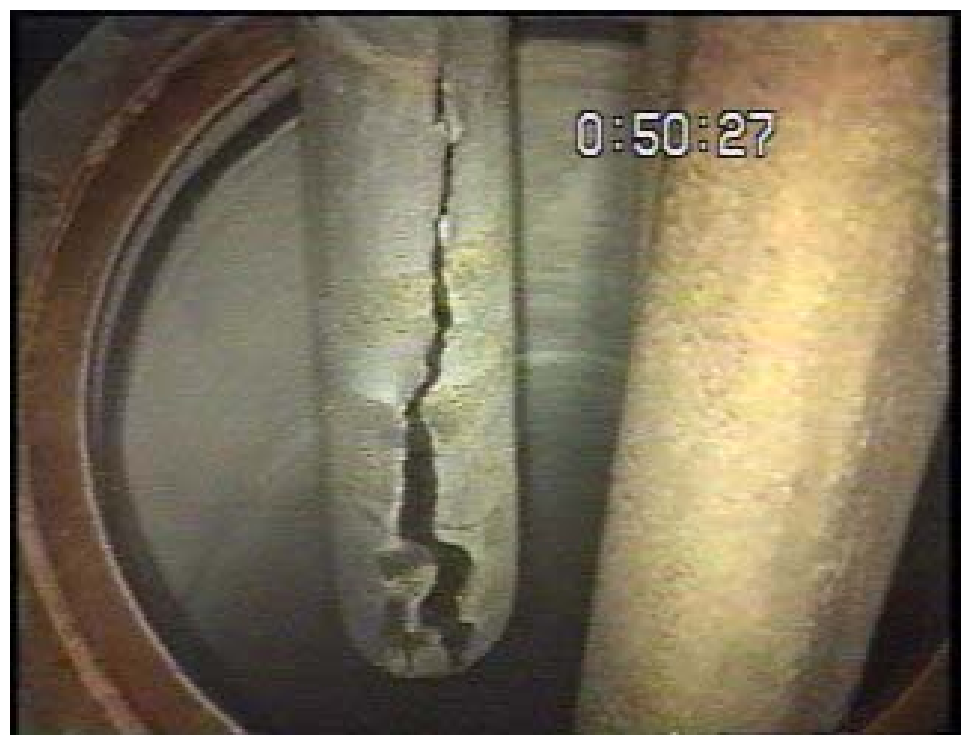

Figure 11. RBOF OS Can Lower Half Showing Contents (ruptured Z-can) Being Removed

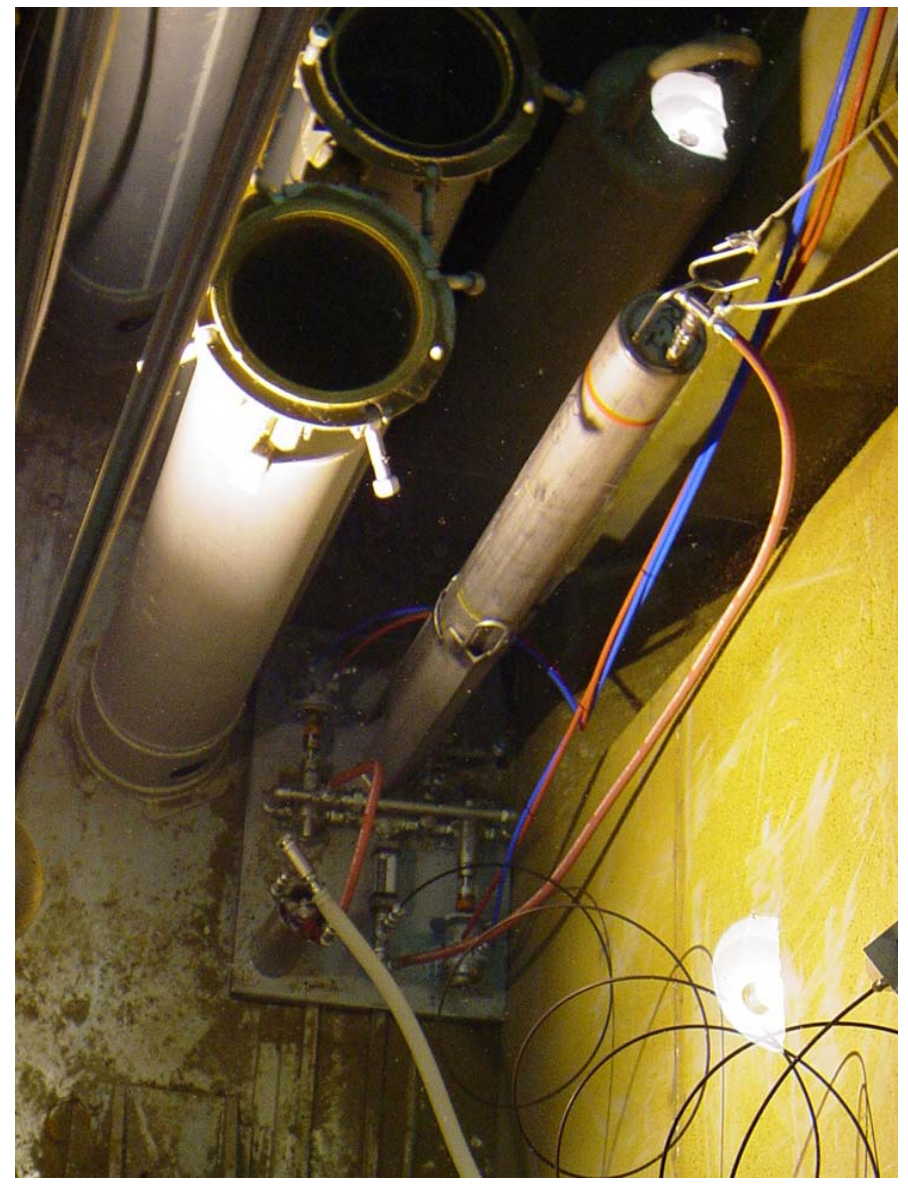

Figure 12. RBOF Underwater deionizer with Empty Oversized Canister Bottom Halves 


\section{WATER CHEMISTRY CONTROL SYSTEM}

Water quality is achieved and maintained by the Water Chemistry Control System. Previous water clean-up involved portable deionization and sludge vacuuming. The WCCS is operated to maintain the water quality parameters of $\mathrm{pH}$, conductivity, and ionic species as shown in Table 5 as part of the Basin Chemistry Control Program [18]. Activity limits for the resin train are established to meet the safety basis for the facility. These limits translate into basin water operational activity limits for cesium and alpha activity as shown in Table 5.

\subsection{DESCRIPTION}

L Basin presently uses anion and cation ion exchange resins for basin chemistry control for control of corrosion of the fuel, and past operation of the WCCS included its zeolite trains. The WCCS system consists of two sand filter trains, one zeolite train (no longer used), and two deionizer resin trains as shown in Figure 13. The sand filter system was installed in 2004 and contains sand and anthracite (coal) to remove insoluble particles. The recirculation flow through the sand filter is $1,800 \mathrm{gpm}$.

A portion of the flow (200 gpm) from the sand filter enters the ion exchange resin systems as indicated in Figure 13. The ion exchange and zeolite systems were installed in 1996. The zeolite train, when used, is a single pass, molecular sieve and ion exchange system that effectively removes cesium and strontium ions from the water after is passes through the sand filters, and before it enters the anion and cation resin trains. The zeolite train has two vessels each of which consist of $50 \mathrm{ft}^{3}$ total of zeolite.

The anion and cation trains are specifically designed to minimize corrosion by removing and replacing any deleterious ions that have not been removed by the zeolite. The ion exchange resins used in the L Basin system are porous polystyrene/divinylbenzene copolymers. The resin is mostly polystyrene with some divinylbenzene cross-linking for strength.

The resins are similar, except for the amount of divinylbenzene and the attached functional groups. The cation resin contains $8 \%$ divinylbenzene and the functional group is $\mathrm{SO}_{3}{ }^{-} \mathrm{H}^{+}$. The anion resin contains $4 \%$ divinylbenzene and the functional group is $\mathrm{CH}_{2}-\mathrm{N}^{+}\left(\mathrm{CH}_{3}\right)_{3} \mathrm{OH}^{-}$.

Each of the two anion vessels contains approximately $70 \mathrm{ft}^{3}$ of resin. Each of the two cation vessels contains approximately $50 \mathrm{ft}^{3}$ of resin. The dual anion and cation train configuration provides redundancy in ion exchange capability and the resin ratio ensures that both resin vessels will be spent at approximately the same time. 


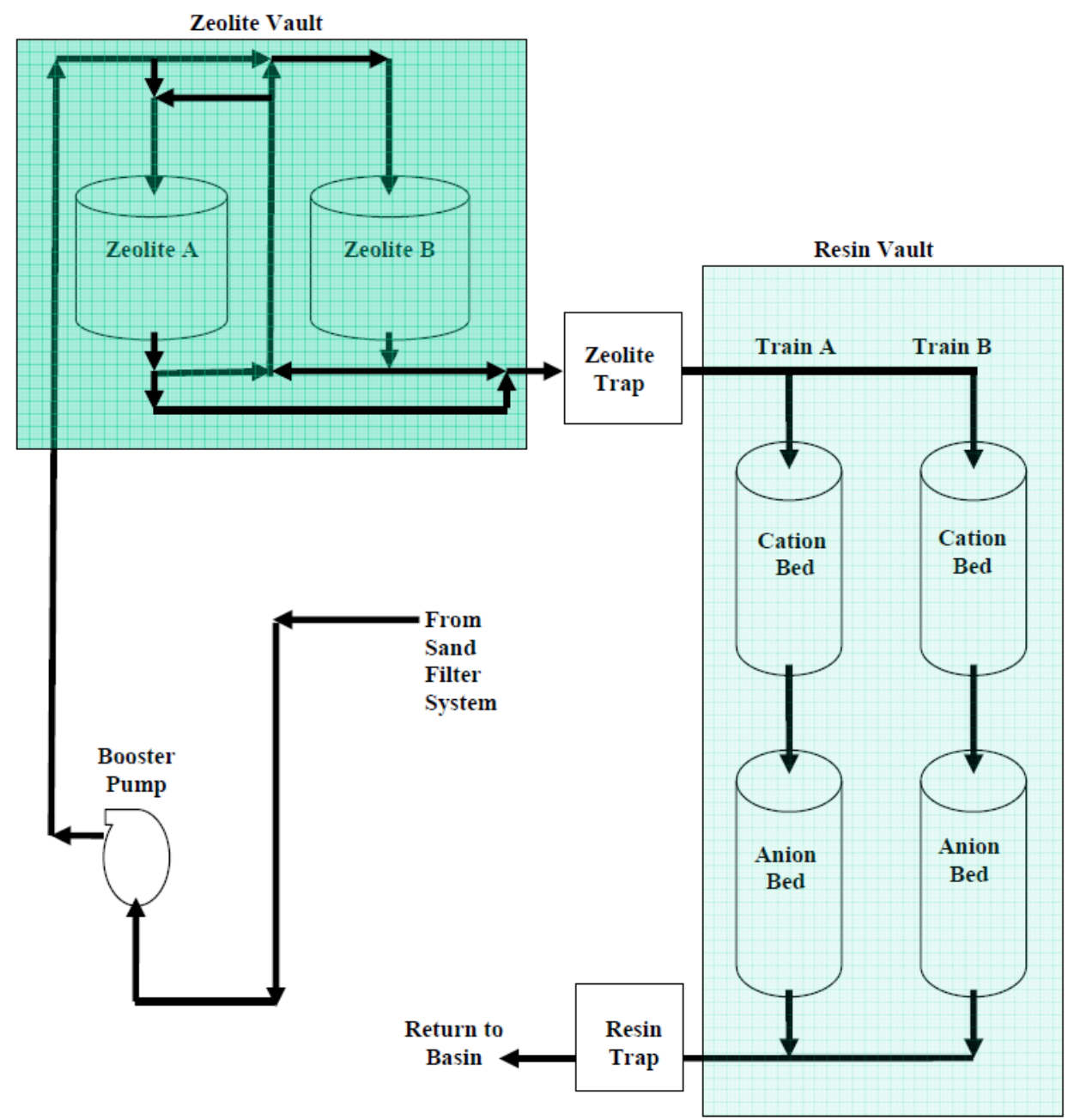

Figure 13. Water Chemistry Control System Layout for L Basin

\subsection{ANALYSIS OF TIME OFF-LINE}

Water impurity species and radioactivity will build up with time when the deionizer is off-line. An evaluation of the transient change in concentration of the impurity species is provided in references 15 and 19.

The $\mathrm{L}$ Basin water radioactivity is primarily due to the concentration of ${ }^{137} \mathrm{Cs}$ in the basin water as determined by chemical analysis of basin water samples. Therefore, modeling radiation release rates from $\mathrm{Al}-\mathrm{SNF}$ into the basin water concentrates on the release rate of ${ }^{137} \mathrm{Cs}$. In general, the release of radioactivity from Al-SNF with breached cladding into water is dependent on several factors:

- $\quad$ area of exposed fuel

- environment (temperature and quality of the water);

- radioisotope content of fuel (enrichment, burn-up, and decay time);

- fuel meat material (post-irradiation composition and microstructure); and 
- clad material

At the low temperatures typical of basin storage (approximately room temperature), corrosion is the primary mechanism whereby species from the fuel core are released into the water. That is, diffusion transport of species from regions in the fuel core to the exposed fuel surface and direct release is not significant.

The radionuclides are assumed to be fully soluble and free to disperse into the water, and not bound in the corrosion product. A simple model to estimate the release from fuel core has been developed by considering general corrosion of the fuel core region directly exposed to the environment [19]. The release model is given by:

$\mathrm{R}=\mathrm{A} \times \mathrm{B} \times \mathrm{C}$

where:

$\mathrm{R} \quad$ is the ${ }^{137} \mathrm{Cs}$ release rate $[\mathrm{Ci} / \mathrm{hr}]$;

A is the ${ }^{137} \mathrm{Cs}$ activity density in the fuel meat material at the decay time of interest $\left[\mathrm{Ci} / \mathrm{cm}^{3}\right]$ (example of $0.412 \mathrm{Ci} / \mathrm{cm}^{3}$ for the RA-3 fuel [19];

B is the area of fuel exposed to the environment (area of breach) $\left[\mathrm{cm}^{2}\right]$; and

$\mathrm{C}$ is the general corrosion rate of the fuel core material in the environment of exposure $[\mathrm{cm} / \mathrm{hr}$ ], that is $5.808 \mathrm{E}-8 \mathrm{~cm} / \mathrm{hr}$ [19].

The activity concentration of the basin is directly related to the pumping rate through the deionizers and the release rate of ${ }^{137} \mathrm{Cs}$ from the existing basin sources and fuel meat material exposed by the through clad penetration. The long-term steady-state activity concentration in the basin will be from these sources. The radioactivity will ultimately reach a steady-state concentration in a basin that has a constant source of impurity specie addition, or release rate, into the water with an online deionization system for the basin. That is, at $\mathrm{t}=$ infinity, the concentration of an impurity specie $\mathrm{C}(\mathrm{t})=\mathrm{C}_{\mathrm{SS}}$. For a closed loop system the steady-state concentration of radioactivity in the water, $\mathrm{C}$ (in $\mathrm{Bq} / \mathrm{L}$ ), is given by (15):

$$
\mathrm{C}_{\mathrm{SS}}=\mathrm{R} /(\mathrm{Q} \varepsilon)
$$

Where $\mathrm{Q}$ is the volumetric flow rate in L/s into and out of a closed loop deionization system, $\mathrm{R}$ is the total release rate of radioactivity into the water in $\mathrm{Bq} / \mathrm{s}, \varepsilon$ is the efficiency of the deionizer system and $\mathrm{C}_{\mathrm{SS}}$ is the activity of the water in $\mathrm{Bq} / \mathrm{L}$ at steady-state.

This equation is was used to determine the impact to the L Basin from storage of breached fuel in reference 19 and also the rate of activity rise with the deionizer off-line. 


\subsection{MAINTENANCE OF WCCS}

An ion exchange resin train operates for about six months before becoming spent. The spent resin train is slurried into a High Integrity Container (HIC) for disposal onsite at the Solid Waste facility. The basin water limits and the resin curie loading are monitored so the DSA assumptions for resin radionuclide content are not violated.

\subsection{PORTABLE DEIONIZATION}

Portable deionizers have been used in the SRS basins, including the most recent use in L Basin. Deionization using the existing SRS portable deionizers began in L Basin in 1994 prior to the present WCCS described above. The used of portable deionizers can provide a ready alternative, if needed to the WCCS.

\subsection{WATER CHEMISTRY MONITORING}

The basin water is sampled for corrosion and radionuclide monitoring puposes. The basin water is analyzed for conductivity, $\mathrm{pH}$ and ${ }^{137} \mathrm{Cs}$ activity weekly, and the results since 2002 are shown in Figure 14. The conductivity and ${ }^{137} \mathrm{Cs}$ activity increases are tied to deionizer operation except for some of the ${ }^{137} \mathrm{Cs}$ activity increases in parts of 2003 and 2004. Some of these ${ }^{137} \mathrm{Cs}$ activity increases were due to cask receipts. A basin water analysis for alpha activity is performed monthly. Every six months the basin water is analyzed for tritium activity, chloride, iron, copper, mercury and aluminum concentrations. The basin water temperature is monitored weekly.

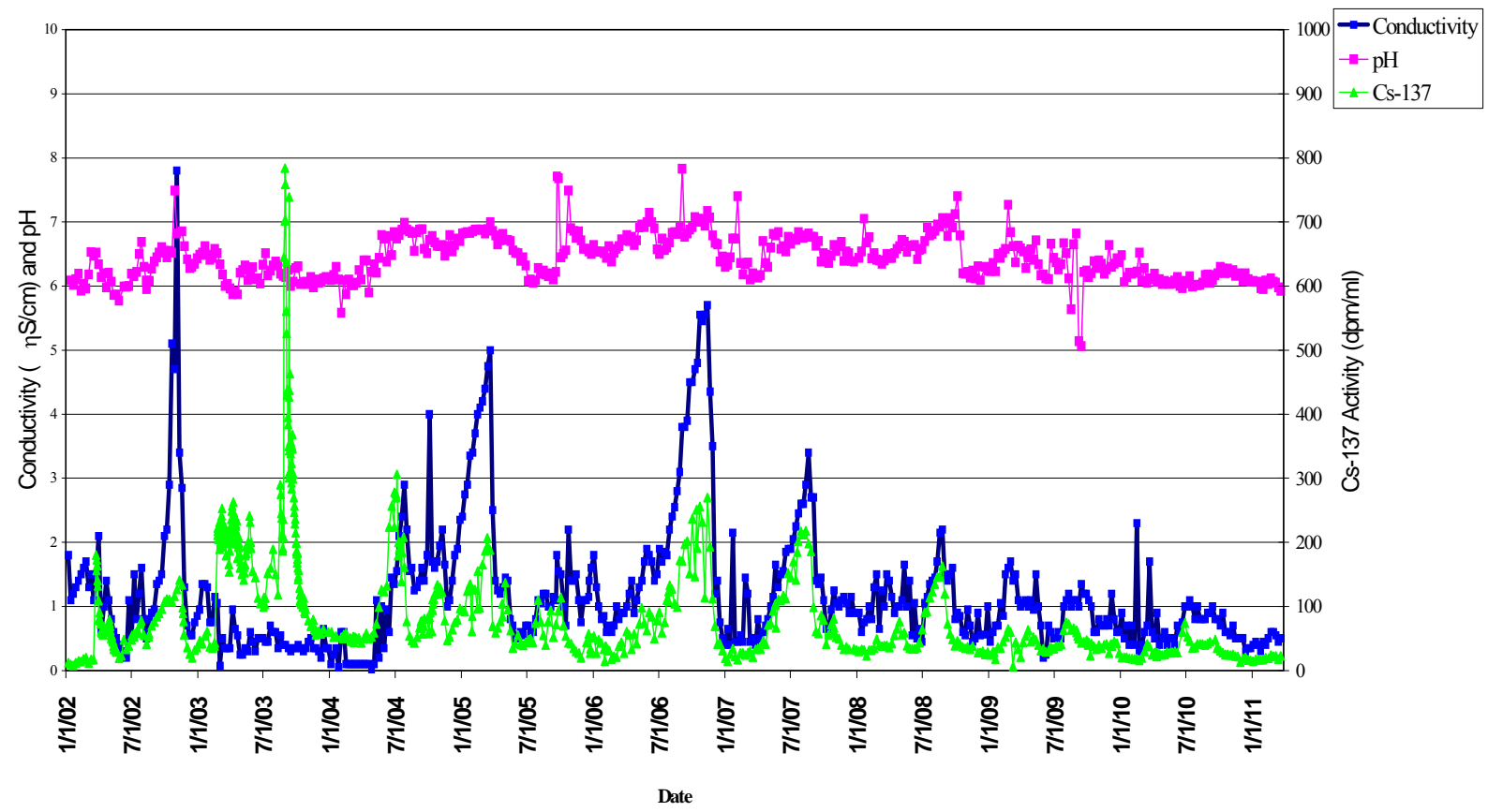

Figure 14 L Basin Water Chemistry - Trend of Weekly Analysis. The water chemistry results can be correlated to basin operations (e.g. cask receipt; deionizer off-line) 


\subsection{CORROSION SURVEILLANCE}

The IAEA has recommended that a corrosion surveillance program is an important part of a water quality management program for research reactor fuel storage [15]. Corrosion surveillance has been performed in the SRS basins since the early 1990s, and a plan for continued surveillance defines the present program [20]. The L Basin corrosion surveillance program provides for early detection of corrosion of the materials of the aluminum cladding and storage racks due exposure to the L Basin water. Early detection of corrosion allows adjustments of basin water quality or fuel storage configuration to mitigate corrosion, as necessary.

Corrosion surveillance involves exposure of a set of test coupons to the L Basin water for a predetermined period, followed by removal and metallurgical evaluation to detect and characterize corrosion. Water quality parameters that are measured at periodic intervals are documented with the corrosion results. The effects of transients in water quality parameters on potential corrosion to the basin materials are captures in the corrosion surveillance program reports.

Figure 15 shows a sketch of a corrosion surveillance coupon sub-assembly to provide a galvanic couple of stainless steel to aluminum.

Figure 16 shows the set "Jr. Ray Gun" set of corrosion coupons in L Basin. At present, coupon sets, located throughout the basin, are withdrawn every two years.

Figure 17 shows the rack used in the immersion of "furniture rack" specimens that are alloys with weldments used in construction of the bundled storage racks.

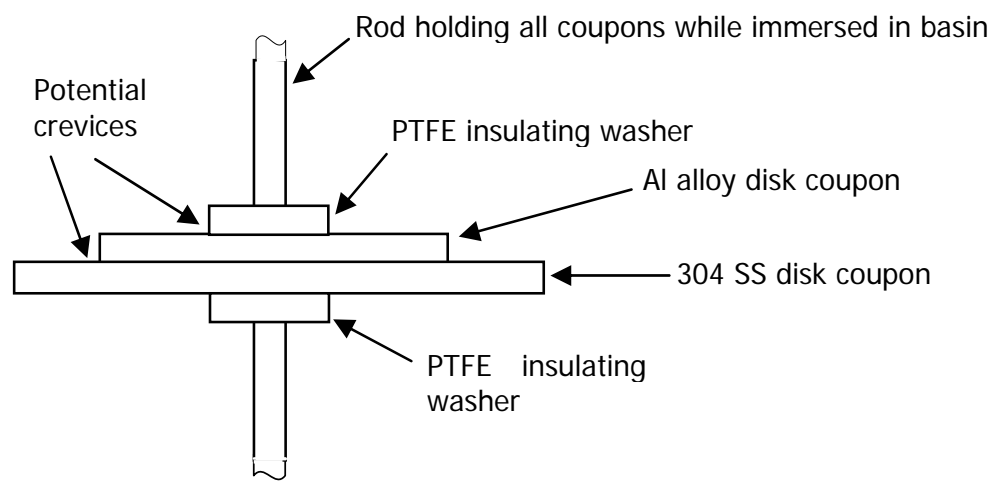

Figure 15 Schematic diagram of a galvanic coupon sub-assembly showing the crevice between the coupons and between the coupons and washers. The corrosion surveillance specimen design allows for determination of general, pitting, crevice, and galvanic corrosion effects to aluminum fuel clad alloys in the $L$ Basin water 


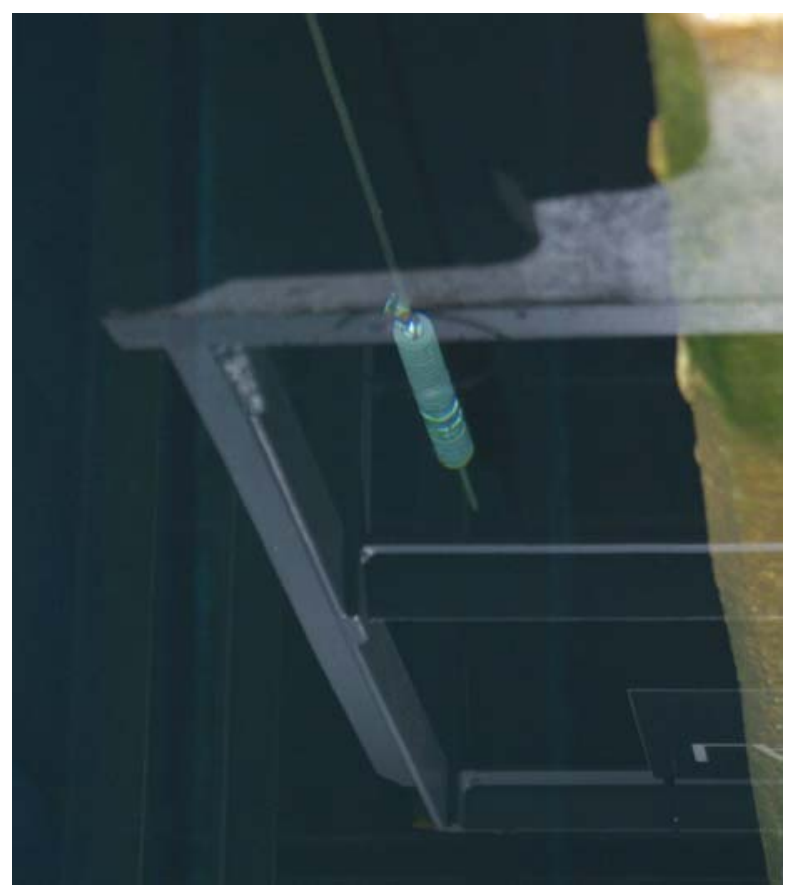

Figure 16 Jr. Ray Gun in Lane 12 shown hanging in VTS in L Basin

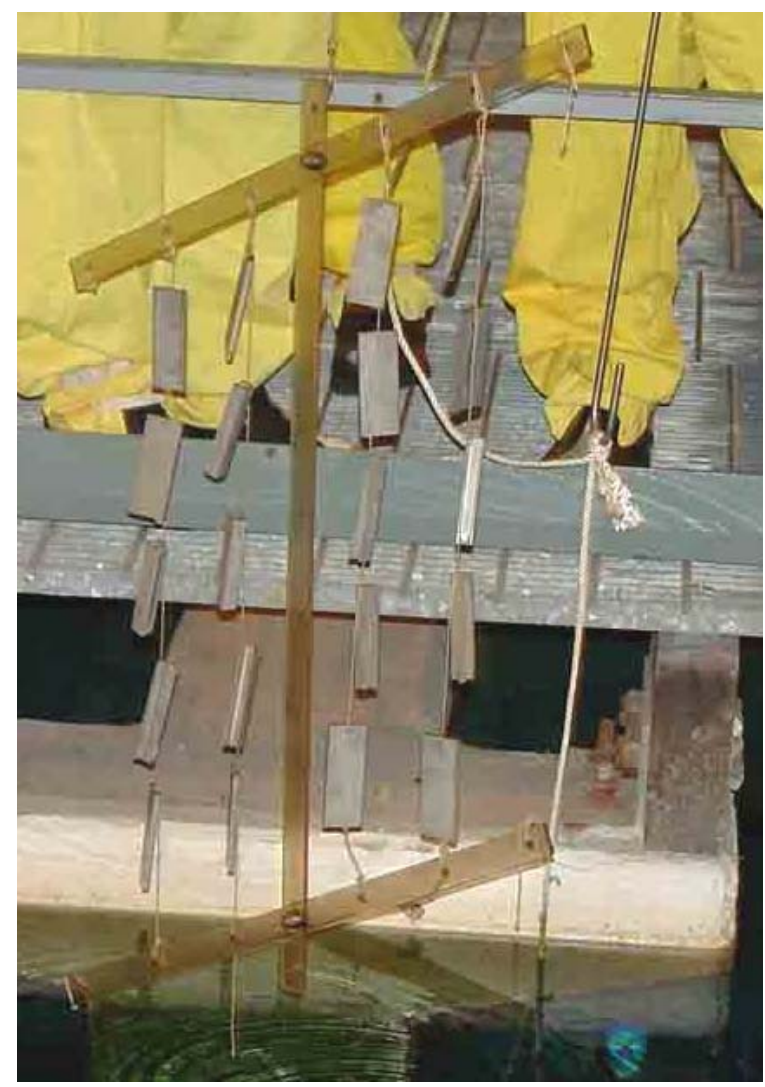

Figure 17 Photo of a typical chimes rack hanging from rail of $L$ Basin. This particular chimes rack is holding 5 furniture rack coupons on each string near HTS handrail number 43 
Specimens from the corrosion surveillance program exhibit expected behavior for general corrosion and localized corrosion. These coupons are specifically designed for increased susceptibility to corrosion attack than would be expected of spent nuclear fuel under identical water chemistry conditions. The following are the general conclusions drawn from the results on corrosion of aluminum fuel and storage rack materials in L Basin that were made in recent corrosion surveillance reports [21,22]:

General Corrosion: A rate for general corrosion of aluminum was determined from $\mathrm{Al}$ 1100 coupons immersed in L Basin for 8.1 years. A general corrosion metal loss of 6.3 $\mu \mathrm{m}$ or $0.41 \mu \mathrm{m} / \mathrm{yr}$ or $0.031 \mathrm{mils} / \mathrm{year}$ was observed.

Localized Corrosion, Crevice Region: Average pit depth increase rate 0.22 mils/year for the immersion period, [average pit depth of 2 mils for 9 -year immersion]. The continued rate of pit growth is much less.

Localized Corrosion, Surface Debris: Average pit depth growth rate 0.4 mils/year for the immersion period, [average pit depth of 3.5 mils for 9 -year immersion]. The continued rate of pit growth is much less.

Localized Corrosion, Galvanic Couples with SS: Average pit depth growth rate 1.7 mils/year for the immersion period, [average pit depth of 15 mils for 9-year immersion]. The continued rate of pit growth is much less.

Localized Corrosion, Rack Materials: Average pit depth increase rates are 1 mils/year or less, with greatest pitting attack in the interface or HAZ region of weld and the weld material itself. The rates are based on dividing the observed pit depths by immersion time in the basin. The continued rate of pit growth is much less.

\subsection{EXPECTED FUEL LIFE IN L BASIN}

The results from the corrosion surveillance program and water chemistry control programs indicate that localize corrosion may occur in crevice conditions and debris deposits.

General corrosion $<<1 \mathrm{mil} /$ year and localized attack $\sim 1 \mathrm{mil} /$ year could occur. Localized attack at the fuel plate - side plate crevice would ultimately lead to side plate dislodging from the fuel and render retrievability difficult. No evidence of additional localized attack has been observed in the fuel stored since water chemistry limits were established, albeit the observations were not optimized to provide detailed imaging of the crevice regions, and time of storage of fuels in L Basin have been less than 20 years. Based on the coupon surveillance results, localized attack is possible even in good quality water, and a period of at least 50 to 100 years may be needed to initiate that localized attack (to concentrate aggressive species in crevice regions of fuel). This conclusion is based in part on the nearly 50 years' storage of aluminum fuel in RBOF with very good water quality and no significant incidence of corrosion attack.

A "re-baseline" of the actual fuel condition would be performed through fuel inspection to provide technical justification of additional storage time of the fuel. 


\subsection{ADDITIONAL PROGRAM ACTIVITIES TO VALIDATE EXTENDED FUEL LIFE}

Maintenance of the water quality and monitoring fuel condition are essential for limiting the corrosion degradation of the fuel and aluminum storage system materials. Additional program activities to improve fuel condition assessment, demonstrate safe storage are:

o periodic inspection of the fuel and storage system materials

o on-line corrosion monitors

o analysis of fuel design/bundled storage for effects of crevices

0 evaluation of fuel-specific changes in fuel canisters

The inspection of the fuel and storage system materials is envisioned to be using remote underwater examination techniques that would include enhanced visual techniques.

Predictive models for fuel condition with time can be developed and benchmarked, as practicable, with laboratory and field data from fuel inspection.

\section{L BASIN STRUCTURE}

The L Basin is the Disassembly Area of the 105-L structure. L Basin is a reinforced concrete structure that holds a water volume of 3,375,000 gallons.

The basin is divided into seven interconnected sections from 17 to 50 feet deep that are configured for spent fuel storage as shown in Figure 4 above. The Documented Safety Analysis [4, section 2.4.1.3] provides a comprehensive narrative description of the Disassembly Area (L Basin) structures as follows:

[L Basin] is a single story reinforced concrete structure with a mat foundation. The Disassembly Area is approximately 160 feet by 230 feet in plan dimensions. The roof is at elevation 15-feet. The structure is divided into an upper (North) and a lower (South) basin by an expansion joint at column line 106. The expansion joint is in the above and below water walls and the ceiling. There is no expansion joint in the floor of the basin at column line 106. The upper basin is predominantly 30 -feet deep with a foundation at least 7-feet thick. The lower basin is predominantly 17 -feet deep with a foundation mat at least 5-feet thick, excluding the Transfer Pit (approximately 2 feet thick). The walls for both basins are nominally 2.5 -feet thick opposite back fill. The walls of the basin adjacent to personnel areas vary between 3 -feet, 1 -inch thick, and 7-feet thick.

To protect the concrete from degradation, the basin walls were coated with an Amercoat 33 vinyl sealer in the early 1980s. This sealer was determined to be degraded beyond its useful life during a Structural Integrity Program [23] baseline inspection performed in the fall of 2004. Engineering judgment, based on available literature, estimated that basin life will be in the order of an additional fifty years. A basin life study has been initiated with the objective of obtaining empirical data to serve as a quantitative basis for basin life. Information from this study will be reviewed against the existing structural analysis. 
The upper basin includes the Vertical Tube Storage (VTS), Dry Cave Basin (DCB), Machine Basin (MB), and Emergency Basin areas. The VTS area has reinforced concrete piers and walkways between underwater fuel storage racks. The walkways are supported on 2-feet square piers by concrete beams that are 2-feet wide by 14 -inches deep. The upper basin is structurally connected to the Process Building in that it shares a common foundation and provides support for the Control Room above the VTS area. The upper basin shares common walls with the Storage Tank Room, hallways on -20' and -40 ' elevations of the Process Building, and the Emergency Pump Room. Pipe penetrations below -33 inches are enclosed in a Controlled Low Strength Material (CLSM) filled pump suction well (44 feet long, 20 feet deep and 3 feet wide). The well is on the east side of the basin adjacent to the Emergency Pump room. The function provided by the Emergency Pump Room is no longer needed. The pumps and piping in the room are retired in place.

The lower basin includes the Horizontal Bundle and Bucket Storage (HBBS), Monitor Basin, and Transfer Bay Areas. Access is provided by walkways supported by concrete piers. The walkways are either concrete, metal grating, or wood. The Transfer Bay Area is where fuel assemblies are transferred to and from shipping casks. The Transfer Bay Area has a higher roof (elevation 40-feet), railway tracks, and support cranes and hoists for handling casks.

Fuel assemblies are transported under water in the Disassembly Area by a system of monorail mounted hoists. The monorails are supported either by rods attached to the ceiling or by steel frames attached to the floor and building columns.

The 2 feet 6 inch thick Disassembly Area roof is supported on beams and columns. The beams and slabs are tapered near supports. The perimeter walls carry both lateral and vertical loads and the interior columns provide vertical support for the roof beams. The roof provides support in certain areas for the monorail system.

Loads on the operating floor include live loads, equipment loads, and supports for the part of the overhead monorail system not suspended from the roof. These loads are carried by concrete piers that also support the walkways. Spent fuel is stored in racks that bear directly on the foundation mat.

\subsection{BASIN STRUCTURAL ANALYSIS}

The 105-L Basin has been successively analyzed since its design and construction in the 1950s for various updates and revisions of seismic codes and requirements.

The first dynamic analysis of the reactor buildings was performed in 1967 through 1969 using the Housner criteria. In 1977 modifications to the 105-L, 105-K, 105-C and 105-P actuator towers of the Process Buildings and to the Stack Buildings were included in the dynamic models. The analysis was performed for the Housner criteria and for the RG 1.60 response spectra of the U. S. Nuclear Regulatory Commission (USNRC), using Structural Engineers Association Of California (SEAOC) guidelines for analysis and ACI Codes for capacities. In 1980s the reactor buildings including 105-L were analyzed for 
an updated Blume spectra. [24, 25]. The design basis response spectrum uses a 5\% damping.

In 1989 soil structure interaction (SSI) was incorporated in the seismic analysis for the USNRC RG 1.60 input spectra, and in-structure floor response spectra were obtained. Updated soil properties were incorporated in the 1991-92 analysis. Soils and geotechnical input provided by the Site Geotechnical Services (SGS) recommended total and differential static settlements [26] based on the historical data of field measurements of benchmark monuments

The structural analysis performed for L Basin incorporated SGS soils and geotechnical input. Based on matching time-history analysis for SSI with various accelerations versus time, the input spectrum is used with a $5 \%$ damping. These present calculations to demonstrate the structural capacity of the L Basin and surrounding structures under design basis loadings are contained in references [27, 28, 29], and references thereto. Asdesigned material properties were used in the analyses. The results of the demand to capacity ratios demonstrate stability against loading and the results, reproduced from reference 27, are in Table 6 below.

Table 6 Critical D/C Ratios for the Lower Disassembly Area [27]

\begin{tabular}{|c|c|c|c|c|}
\hline Element & Loading & D/C & $\begin{array}{c}\text { Calc Sheet / } \\
\text { References }\end{array}$ & Comments \\
\hline $\begin{array}{c}\text { Exterior wall } \\
\text { (Transfer Area) }\end{array}$ & Seismic & 0.35 & $\begin{array}{c}\text { Ref 1 (Vol I), } \\
\text { Sh 11 }\end{array}$ & 0.40 with $\phi=0.75$ \\
\hline $\begin{array}{c}\text { Exterior wall } \\
\text { (Lower Disassembly Area) }\end{array}$ & Seismic & 0.20 & $\begin{array}{c}\text { Ref 1 (Vol I), } \\
\text { Sh 11 }\end{array}$ & 0.23 with $\phi=0.75$ \\
\hline Wall Out-of-Plane & $\begin{array}{c}\text { Lateral Soil } \\
\text { Pressure }\end{array}$ & 0.97 & $\begin{array}{c}\text { Ref 1 (Vol I), } \\
\text { Sh 11 }\end{array}$ & Conservative $\mathrm{K}_{0}$ of 0.70 \\
\hline Roof Shear & $1.2 \mathrm{D}+1.6 \mathrm{~L}$ & 0.84 & 50 & --- \\
\hline Roof Flexure & $1.2 \mathrm{D}+1.6 \mathrm{~L}$ & 0.83 & 59 & -- \\
\hline
\end{tabular}

Basin leak rates following NPH and process events were developed based on these soil characteristics and post event ground settlement $[30,31]$.

The wind and tornado analysis of the 105-L Basin building performed in 2002 [28] showed the building capacity to exceed the PC-3 design basis wind speeds.

\subsection{BASIN MATERIALS CONDITION}

Periodic inspection and condition assessments of the L Basin are performed as part of the Structural Integrity Program (SIP) [23]. Under the program's guidelines established in 2005, a fairly thorough visual inspection of the entire 105-L structure is performed every 6 years to establish a baseline condition, identifying anomalies for repair or continued monitoring. This baseline inspection is required to be performed with Structural Mechanics (SM) and Savannah River National Laboratory Materials Science \& Technology (Materials) personnel as Subject Matter Experts. In the interim years, the SIP coordinator performs a variety of annual inspections to monitor the general condition of the facility. The results of all periodic inspection activities are reviewed annually by a 
committee whose members include facility and engineering management, as well as the SM and Materials experts, as a follow-up action for all inspection results.

With respect to the basin, the 6 year visual inspections can be divided into the abovewater walls and ceiling in Disassembly, the underwater structures, and the accessible external surfaces of the basin walls in the adjoining rooms on the -20' and -40' levels. Underwater camera inspections of the basin structures such as walls, flooring columns and beams were performed in FY 2005 to assess the condition of the structures and establish the baseline condition. SM and Materials experts were part of the team led by SFP Engineering in planning and executing the visual inspections of the L Basin as a baseline for the SIP. The inspection plan was issued and reviewed in preparation for conducting the inspection [32]. The results of periodic inspection activities are reviewed, annually, as a follow-up action for all inspection results.

SRS Engineering Guide 01101-G was utilized for the visual inspections. Guidelines for the evaluation of existing nuclear safety related concrete structures given in section 9 of ACI $349.3 \mathrm{R}$ were the primary source for the visual inspection evaluation, acceptance criteria, and making recommendations. The inner wall was inspected for degradation indicators such as pitting or spalling. No significant pitting or spalling was observed; therefore the wall is judged to have insignificant degradation. A summary of the condition of the basin is contained in the Structural Integrity Information Sheets [33].

The Amercoat 33 coating applied in the 1980s is judged to be beyond its effective life due to blisters, peeling, and decomposition. Cracks are expected in the surface of the concrete due mainly to shrinkage cracking. Due to the presence of paint or slight etching of the surface where the concrete is bare, these small cracks are not visible. In some instances they may have been widened at the surface for patch repair during 1980's L Reactor Restart. Visual inspection of the external surfaces of the basin walls in several locations shows that water has historically migrated through the walls. Specifically, the water moving through the concrete over time picks up soluble salts (from radioactive materials such as Cs-137 in the basin water and stable isotopes in the concrete) and deposits them on the exterior of the walls in the form of efflorescence or a stalactite type formation as shown in Figure 18 below. This particular photo was taken in the Moderator Storage Tank Room at a crack location on the west wall of the VTS basin, at approximately the -15 ' level. 


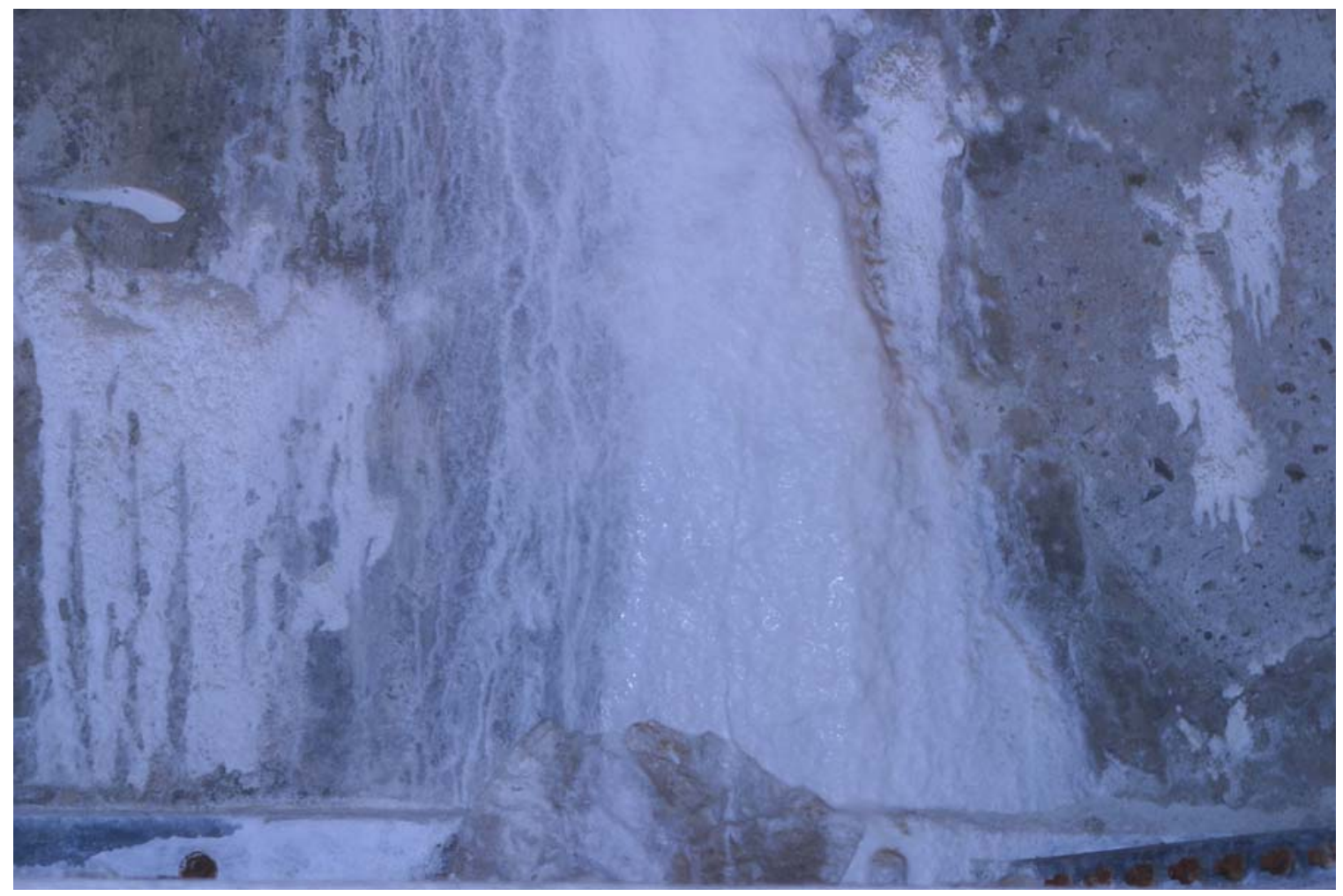

Figure 18 Build-up Deposits of Calcium Carbonate due to Leakage Through Minor Cracks in L Basin [photograph April 2010]

One area that has heightened awareness is stalactite formation on the exterior wall of the D\&E Canal. This calcium deposit does not show signs of rebar corrosion and the rate of water dripping from the stalactites has continually decreased since they were initially recorded in 2005.

Structural analysis calculations for 2500 psi concrete are considered conservative because the concrete, initially, gains strength with age. Based on the visual inspection made in 2004 and 2005 and subsequent reviews documented in References 34 and 35, it is unlikely that any significant area of the basin has degraded below the 2500 psi strength.

The above ground concrete building enclosure, the columns, the piers, and the walkways were also inspected in FY 2005 and found to have no significant degradation.

Based on the above observation, it is concluded that there is no significant degradation of the concrete in the L Basin or the 105-L building structures that invalidates the structural analysis.

The 6-year interval inspection of the facility was recently completed in April 2011. No significant degradation from the conditions noted in 2005 has occurred, nor were any structural concerns noted. 
A topical report on the L Basin life expectancy was prepared in 2008 by a team of materials and structural experts to assess the remaining life of the L Basin structure [36]. The primary conclusion of that report is that the L Basin is fully expected to maintain its structural stability against defined NPH events in consideration of materials degradation and aging until at least 2058.

\subsection{ADDITIONAL PROGRAM ACTIVITIES TO VALIDATE EXTENDED BASIN LIFE}

Periodic inspection of the L Basin is performed under the L Basin SIP to provide condition assessments. These inspections are considered necessary for continued use of L Basin to monitor materials degradation.

Additional materials sampling (core harvesting in L Basin or similar structures) to evaluate potential degradation phenomena of calcium leaching (water side) and carbonation and sulfate attack (air and soil side) is recommended to evaluate depth of degradation of the concrete. Results of the depth of degradation would be considered in revised structural analysis, as appropriate.

Periodic inspection and evaluation and trending of materials degradation of L Basin as input to structural analysis against required loading events would be needed be continue to demonstrate its fitness for service. There are no indications at present for a life limiting degradation process for the L Basin structure. Continued use for at least an additional 50 to 100 years is judged to be achievable.

\section{CONCLUSIONS}

It is concluded that the technical bases and well-founded technologies have been established to store spent nuclear fuel in the L Basin. Methodologies to evaluate the fuel condition and characteristics, and systems to prepare fuel, isolate damaged fuel, and maintain water quality storage conditions have been established. Basin structural analyses have been performed against present NPH criteria.

The aluminum fuel storage experience to date, supported by the understanding of the effects of environmental variables on materials performance, demonstrates that storage systems that minimize degradation and provide full retrievability of the fuel up to and greater than 50 additional years will require maintaining the present management programs, and with the recommended augmented/additional activities in this report.

\section{REFERENCES}

\footnotetext{
${ }^{1}$ R.L. Sindelar, D.W. Vinson, N.C. Iyer, and D.L. Fisher, "Overview of Criteria for Interim Wet \& Dry Storage of Research Reactor Spent Nuclear Fuel," in proceedings of International Atomic Energy Agency Technical Meeting, Dounreay, Thurso, U.K., "Guidelines of Good Practices for the Management and Storage of Research Reactor Spent Fuel, October 19-23, 2009," to be published.
} 
2 IAEA Safety Standard Series, Safety Guide No. NS-G-4.3, "Core Management and Fuel Handling for Research Reactors."

${ }^{3}$ AEA Safety Standard Series, Safety Guide No. NS-G-1.4, "Design of Fuel Handling and Storage Systems for Nuclear Power Plants."

${ }^{4}$ WSRC-SA-2004-00002, Rev. 6, "L-Area Material Storage Facility Documented Safety Analysis," September 2010.

${ }^{5}$ S-TSR-L-00002, “Technical Safety Requirements, Savannah River Site, L Material Storage Facility,” Revision 7, June 2010.

${ }^{6}$ Nuclear Safety Management, Code of Federal Regulations, Title 10 Part 830, U.S. Department of Energy, Washington, D.C.

${ }^{7}$ U.S. Department of Energy. DOE/EIS-0218F, U.S. Department of Energy, Washington, D.C., "Department of Energy Final Environmental Impact Statement on a Proposed Nuclear Weapons Nonproliferation Policy Concerning Foreign Research Reactor Spent Nuclear Fuel,” February, 1996.

${ }^{8}$ U.S. Department of Energy. DOE/EIS-0218-SA-2; "Supplemental Analysis of Acceptance of Foreign Research Reactor Spent Nuclear Fuel Under Scenarios not Specifically Mentioned in the EIS," August 1998.

${ }^{9}$ U.S. Department of Energy. DOE/EIS-0218-SA-3, "Supplement Analysis for the Foreign Research Reactor Spent Nuclear Fuel Acceptance Program,” November 2004.

${ }^{10}$ SRNS-N0000-2009-00142, "Nuclear Materials Storage and Disposition System Plan," K.S. Fuller, April 28, 2010.

${ }^{11}$ SRNL-N0000-2010-00028, "Nuclear Materials Storage and Disposition Planning Assumptions List, FY11-FY23,” K.S. Fuller, November 18, 2010.

${ }^{12}$ Si Y. Lee, R.L. Sindelar, and D.C. Losey, "Thermal Modeling and Performance Analysis of Interim Dry Storage and Geologic Disposal Facilities for Spent Nuclear Fuel," Nuclear Technology, Vol. 131, July 2000, pp. 124-151.

${ }^{13}$ M\&O-SFP-2008-00065, “SNF Transfer Program Plan,” June 25, 2008.

${ }^{14}$ M-TRT-L-00003, R.W. Deible, “Spent Fuel Isolation Cans Inventory,” March 2005.

${ }^{15}$ International Atomic Energy Agency, "Recommended practices for water quality management in research reactors \& spent fuel storage facilities," IAEA Nuclear Energy Series, to be published 2011.

${ }^{16}$ SRNS-TR-2008-00034, P.R. Vormelker, "FY2005 and FY2007 Furniture Rack Coupon Surveillance Results for L- Basin," October 2008.

${ }^{17}$ D. L. Fisher; N.C. Iyer; R.L. Sindelar, and T.J. Spieker; International Atomic Energy Agency. International Conference on Management of Spent Fuel from Nuclear Power Reactors. Paper 
IAEA-CN-178/09-03 at IAEA T1-CN-178, "Damaged fuel storage and recovery - a case study, 2010."

${ }^{18}$ WSRC-TR-97-0239, Rev. 5, R.W. Deible, “L Basin Water Chemistry Control Program (U).”

${ }^{19}$ WSRC-TR-97-0153, R. L. Sindelar and J.P. Howell, "Radioactivity Release from AluminumBased Spent Nuclear Fuel in Basin Storage (U)," (May 1997); results also in R.L. Sindelar, S.D. Burke, and J.P. Howell, "Evaluation of Radionuclide Release from Aluminum-Based SNF in Basin Storage," Proceedings of the Third Topical Meeting on DOE Spent Nuclear Fuel and Fissile Materials Management, Charleston, SC, p. 259-264 (September 1998).

${ }^{20}$ SRNL-TR-2009-00140 Rev.1, P.R. Vormelker and R.W. Deible, "L Basin Corrosion Surveillance Program Plan,” September 2009.

${ }^{21}$ SRNL-TR-2009-00256, P.R. Vormelker and C.N. Foreman, "FY2008 Corrosion Surveillance Report," December 2009.

${ }^{22}$ SRNS-TR-2008-00034, P.R. Vormelker and T.H. Murphy, "FY2005 and FY2007 Furniture Rack Coupon Surveillance Results for L Basin (U),” February 2009.

${ }^{23}$ WSRC-TR-2004-00307, Rev. 2, “105-L Structural Integrity Program,” Westinghouse Savannah River Company, Aiken, SC. , July 2007

${ }^{24}$ Update of Seismic Criteria for the Savannah River Plant, Volume 1, URS/John A. Blume and Associates, Engineers, 1982, Geotechnical: URS/JAB 8144, San Francisco, CA, prepared for E. L du Pont de Nemours and Company, (Documented at SRS as DPE 3699)

${ }^{25}$ Update of Seismic Criteria for the Savannah River Plant, Volume 2, URS/Blume, John A. \& Associates, URS/JAB8144, June 1984. (Documented at SRS as DPE3899)

${ }^{26}$ Liquefaction Potential and Settlement Estimate for 105. K-CLC-L-00005, Rev. 1, Westinghouse Savannah River Company, Aiken, SC

${ }^{27}$ 105-L Process Building - Seismic Evaluation. T-CLC-L-00051, Rev. 3, Westinghouse Savannah River Company, Aiken, SC

${ }^{28}$ NPH Evaluation of 105-L Disassembly Basin. T-CLC-L-00061, Rev. 0, Westinghouse Savannah River Company, Aiken, SC.

${ }^{29}$ Disassembly Basin - Structural Evaluation of Walkways, Columns, and Floor Loads. T-CLCL-00064, Rev. 0, Westinghouse Savannah River Company, Aiken, SC.

${ }^{30}$ 105-L Disassembly Basin: Seepage Analysis. T-CLC-L-00014, Rev. 4, Westinghouse Savannah River Company, Aiken, SC.

${ }^{31}$ L-Basin Drain Down Rates, T-CLC-L-00098, Rev. 0, Westinghouse Savannah River Company, Aiken, SC

${ }^{32}$ Structural Integrity Program - Baseline Inspections of L-Basin, Technical Memorandum \# SRT-MTS-2004- 30003, May 26, 2004 
${ }^{33}$ 105-L Structural Integrity Information Sheets, WSRC-TR-2005-00303, Rev. 3, Westinghouse Savannah River Company, Savannah River Site, Aiken, SC.

${ }^{34}$ Structural Integrity Annual Review, M\&O-SFP-2006-00112, October 2, 2006

${ }^{35}$ L-Area FY 2007 Structural Integrity Inspection Summary, M\&O SFP-2007-00149, October 2, 2007

${ }^{36}$ WSRC-TR-2008-00202, "L Basin Life Expectancy,” Washington Savannah River Company, July 2008. 
SRNL-STI-2011-00190

SRNS INTERNAL DISTRIBUTION

W.F. Bates, 717-K

R.R. Reichel, 704-L

T.M. Monahon, 705-K

D.B. Rose, 705-K

T.J. Spieker, 704-L

M.D. Shaffer, 704-L

M.D. Dunsmuir, 704-L

R.W. Deible, 704-L

R.B. Castles, 704-L

D.L. Speed, 704-25L

N.C. Iyer, 773-41

G.T. Chandler, 773-A

R. L. Sindelar, 773-41A

A.J. Duncan, 773-A

S.A. Carey, 730-1B

N.A. Doulgerakis, 730-1B

W.C. Crouch, 773-41A

DCR Records 